\title{
Alternative splicing of the $O C C-1$ gene generates three splice variants and a novel exonic microRNA, which regulate the Wnt signaling pathway
}

\author{
HADI NAJAFI, ${ }^{1}$ BAHRAM M. SOLTANI, ${ }^{1}$ SADAT DOKANEHIIFARD, ${ }^{1}$ SHIRZAD NASIRI, ${ }^{2}$ \\ and SEYED JAVAD MOWLA ${ }^{1}$ \\ ${ }^{1}$ Department of Genetics, Faculty of Biological Sciences, Tarbiat Modares University, 14115-116 Tehran, Iran \\ ${ }^{2}$ Tehran University of Medical Sciences, Shariati Hospital, 1411713135 Tehran, Iran
}

\begin{abstract}
The Wnt signaling pathway is hyperactivated in most colorectal cancers (CRC). Finding new regulators of this pathway represents the potential for cancer diagnosis or treatment. OCC-1 was initially reported as an up-regulated gene in colon carcinoma, without knowing its mechanism of action. Here, two novel transcript variants and an exonic microRNA that originated from the OCC-1 gene are reported, showing positive effects on Wnt activity. Up-regulation of the known OCC-1 variant (assigned as OCC-1A/B) was limited to CRC, and its overexpression increased survival of CRC-originated SW480 cells (Wnt ${ }^{+}$), while resulting in apoptosis of Wnt-suppressed SW480 cells or HeLa cells $\left(\mathrm{Wnt}^{-}\right)$detected by PI staining. Immunocytochemistry showed that the OCC-1A/Bencoded peptide was localized to the nucleus, where its overexpression resulted in Wnt signaling up-regulation, detected by TOP/ FOPflash assay. The noncoding portion of the $O C C-1 A / B$ transcript had a suppressive effect on Wnt activity and had a negative correlation with APPL2 neighboring gene expression. Unlike $O C C-1 A / B$, the novel $O C C-1 C$ splice variant had no expression alteration in CRC, and it seemed to encode a smaller peptide with cytoplasmic localization. A 60-nucleotide (nt) fragment containing an AUG start codon is spliced out to produce an OCC-1D noncoding RNA variant. The 60-nt RNA was validated as the precursor of a novel microRNA, which we named miR-ex1. Both OCC-1D and miR-ex 1 were coordinately up-regulated in CRC. MiR-ex1 functional analysis revealed that it is targeting the APC2 tumor suppressor gene and is an activator of the Wnt signaling pathway. Overall, the OCC-1 gene is now introduced as a novel Wnt signaling regulator and as a potential therapeutic target.
\end{abstract}

Keywords: colorectal cancer; Wnt pathway; alternative splicing; microRNA; OCC-1; APPL2

\section{INTRODUCTION}

Colorectal cancer (CRC) is the third most commonly diagnosed cancer in males and the second in females (Jemal et al. 2011). Both environmental and genetic factors contribute to CRC development. While contribution of genetic factors is estimated to be $35 \%$, over $25 \%$ of this contribution is unknown yet (Lichtenstein et al. 2000). Genetic alteration of Wnt signaling components, which results in signaling pathway overactivation, is a crucial genetic event in CRC development (Bienz and Clevers 2000; Lustig and Behrens 2003; Segditsas and Tomlinson 2006; The Cancer Genome Atlas Network 2012). For example, mutations of $A P C$ and $\beta$-catenin occur in a high proportion of sporadic CRC (up to $80 \%$ and $10 \%$, respectively) (Schlosshauer et al. 2000). Other than mutations, there are other side players that modulate the Wnt signaling pathway (Huang and He 2008). Finding new players in

Corresponding author: soltanib@modares.ac.ir

Article is online at http://www.rnajournal.org/cgi/doi/10.1261/rna.056317. 116. the Wnt signaling pathway will likely yield a better understanding of Wnt signaling involvement in CRC. These new factors would be promising prognostic markers or therapeutic targets. There were preliminary data suggesting that human locus 12q23.3 might be a novel CRC susceptible locus (Pibouin et al. 2002). In this locus, the Overexpressed in Colorectal Carcinoma-1 (OCC-1) gene (officially named C12orf75; NCBI gene ID: 387882) was initially reported as an up-regulated gene in CRC. The OCC-1 gene consists of 11 exons (Fig. 1A) and its genomic DNA spans a region of $\sim 164 \mathrm{~kb}$ on 12q23.3 (hg38: nt 105,235,250-105,398,725). Current human GENCODE release (version 25) revealed that it transcribes five different splicing RNA variants, two of them (OCC-1A and OCC-1B) are similarly spliced (with the same six exons) but different in lengths of their $5^{\prime}$ - and

(c) 2016 Najafi et al. This article is distributed exclusively by the RNA Society for the first 12 months after the full-issue publication date (see http:// rnajournal.cshlp.org/site/misc/terms.xhtml). After 12 months, it is available under a Creative Commons License (Attribution-NonCommercial 4.0 International), as described at http://creativecommons.org/licenses/by-nc/4.0/. 

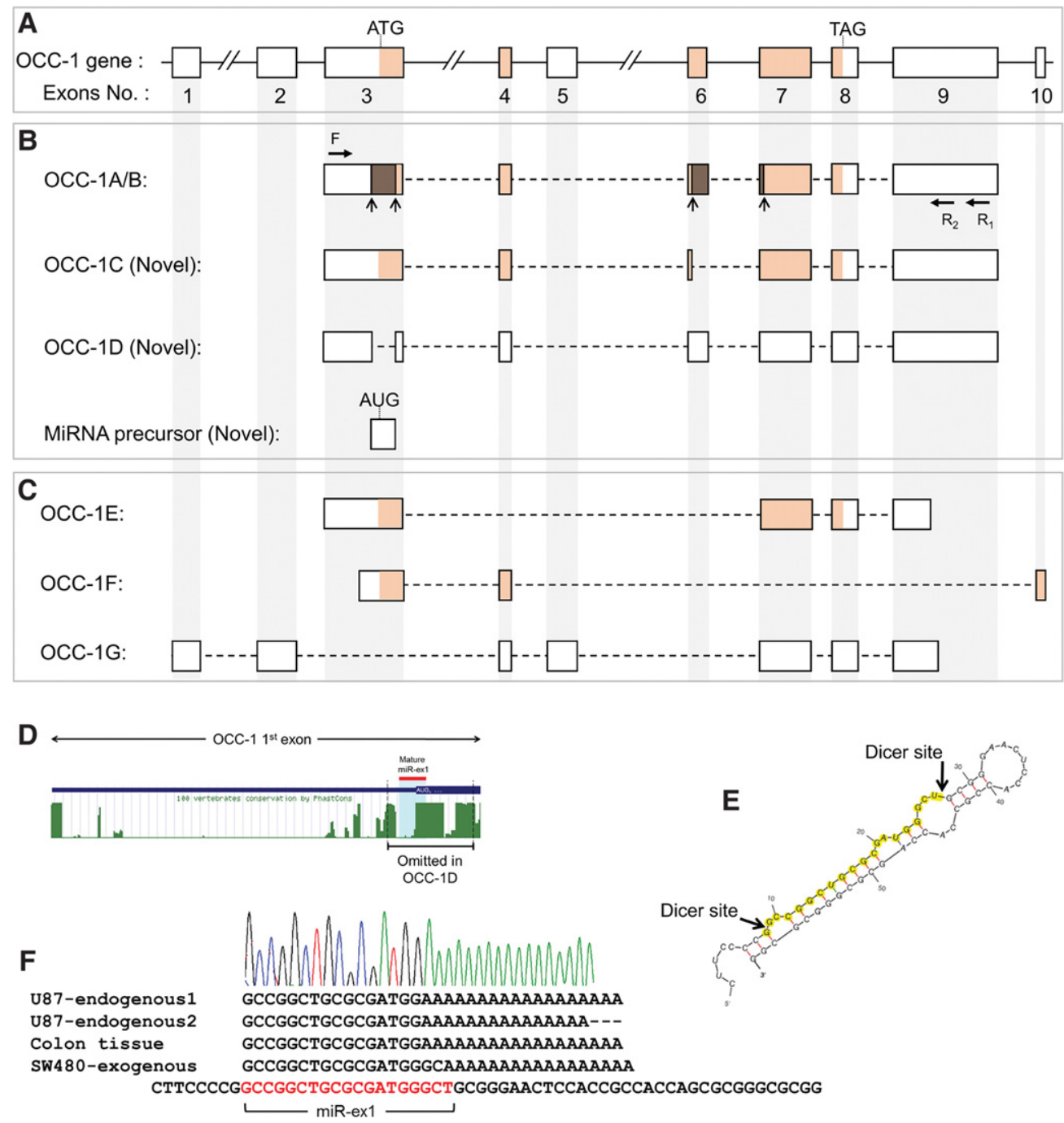

FIGURE 1. Introducing novel splice variants of the OCC-1 gene. (A) Exon-intron architecture of the OCC-1 gene based on GENCODE v25. It consists of 10 exons and nine introns shown by boxes and horizontal lines, respectively. Dark segments in exons delineate their coding feature after processing into corresponding mRNA. (B) Schematic representation of novel OCC-1 splice variants compared to the known $(O C C-1 A / B)$ transcript. In $O C C-1 A$ and $O C C-1 B$ variants (combined and represented as $O C C-1 A / B$ ), exons are similarly spliced at the conventional splice sites, but for the production of the OCC-1C variant, alternative $5^{\prime}$ and $3^{\prime}$ splice sites within exon 6 and exon 7 (denoted as vertical arrowheads) are used, respectively. For production of the OCC-1D variant, an intra-splicing event has occurred inside the first exon of $O C C-1 A / B$, causing elimination of a 60 -nucloetide (nt) fragment containing the OCC-1 start codon. Boxes represent exons, and the positions of UTR-specific primers for amplification of OCC-1 splice variants are shown as horizontal arrows. Vertical arrowheads mark the novel splice sites, shown at the bottom of OCC-1A/B exons. (C) Additional OCC -1 splice variants that are reported by others elsewhere (without characterization) and that are not detectable by our primer sets. $(D)$ Conservation status of the third exon of the OCC-1 gene created by UCSC. Highly conserved area is omitted in OCC-1D, which encompasses the translation start site of the gene. $(E)$ Eliminated 60-nt RNA fragment from the OCC-1 transcript shows characteristics of a pre-miRNA structure. Location of the validated mature miR-exl is highlighted as well as the predicted dicer cutting sites. $(F)$ Sequence alignment of four different TA-vector clones containing a mature miR-exl sequence from different sources and their comparison with the miR-exl precursor.

$3^{\prime}$-ends (Pibouin et al. 2002). Recently, a 63-amino acid (aa) protein has been attributed to these transcripts with a suggested function in stemness and adipogenesis (Kikuchi et al. 2009). However, the exact function of the OCC-1 gene is not clearly known yet. APPL2 gene (NCBI gene ID: 55198), also known as DIP-13 (DCC interacting protein 13- $\beta$ ), is located upstream of the OCC-1 gene with an $\sim 970$ bp overlapping region. The APPL2 protein belongs to the APPL protein family (Miaczynska et al. 2004) whose structure and function is well known, and they have a diverse set of functions (Schenck et al. 2008). The downstream region of OCC-1 is vacant of any coding gene with the exception of the processed ST13 pseudogene 3 (ST13P3) (NCBI gene ID: 144638). This pseudogene is just inferred from homology (Sossey-Alaoui et al. 2002) without any reported transcript. Nevertheless, the OCC-1 downstream region contains several reported ESTs that are not well characterized yet. Some of these ESTs belong to the Cancer Susceptibility Candidate 18 (CASC18) 
(NCBI gene ID: 101929110) gene, which was recently classified as a long noncoding RNA in the human genome (Derrien et al. 2012).

Here, three novel transcripts of the OCC-1 gene are introduced; two of them, including a novel miRNA, are shown to be associated with the Wnt signaling pathway. We also show that the OCC-1 gene affects the transcription level of its neighboring gene APPL2.

\section{RESULTS}

\section{Identification of two novel splice variants of the OCC-1 gene and a novel exonic microRNA}

The previously reported variants of OCC-1 (OCC-1A and $O C C-1 B$ ) contain a common central region but differ in their 5' - and 3'-ends. A single accession number (NM_001145199) represents both variants in the GenBank, and here we have referred to them as the $O C C-1 A / B$ transcript variant. By using $O C C-1$ specific primers against a cDNA library (originated from U87 cell line), two novel OCC-1 splice variants were discovered, designated as OCC-1C (GenBank acc. \#: AB735447) and OCC-1D (GenBank acc. \#: AB735446) (Fig. 1B). Conventional donor and acceptor splice sites between exons 6 and 7 of the gene have been shifted inside (shown by vertical arrows in Fig. 1B), causing a 36-nt deletion of $O C C-1 A / B$ to produce an $O C C-1 C$ variant (Fig. $1 B)$. Using two cryptic splice sites within the third exon of the OCC-1 gene, $60 \mathrm{nt}$ including the $O C C-1 A / B$ start codon is spliced out, generating an OCC-1D variant (Fig. 1B).

Three additional splice variants (here we refer to them as $O C C-1 E, O C C-1 F$, and $O C C-1 G$ ) have also been recently reported in NGS data, however, the primers that have been used for the amplification of $O C C-1 A / B, O C C-1 C$, and $O C C-1 D$ were not suitable for the amplification of other variants (Fig. 1C). Both OCC-1C and OCC-1D are also detectable in the recent NGS databases (Supplemental File S1).

Interestingly, the DNA segment corresponding to the spliced out 60-nt RNA fragment represented a saddle-like conservation plot, which is a prominent characteristic of miRNA precursors (Fig. 1D), and RNA fold software predicted a stem-loop structure for it (Fig. 1E). This stem-loop (nominated as pre-mir-ex1; acc. \#: HF679086) had multiple characteristics of a putative miRNA precursor (Supplemental File S2). Furthermore, pre-mir-ex1 and its predicted mature form, miR-ex1, were PCR amplified from a U87 cell line cDNA preparation. PCR products were cloned in TA vectors and sequencing of several colonies indicated that 19-nt-long mature miRNA is produced. The identity of miR-ex1 (acc. \# LT601573) was confirmed by alignment of the sequencing results with the sequence of the miR-exl precursor (Fig. 1F). $M i R$-ex1 expression was also detected in other human cell lines (Supplemental File S4-3C) and its sequence is detectable in a recent NGS database (Supplemental File S2). To date, no identical miRNA has been reported in the miRbase database for $m i R$-exl.

\section{Differential expression pattern of novel OCC-1 splice variants}

To analyze the expression pattern of $O C C-1$ splice variants in human cells, specific primers at unique exon-exon junctions were designed and PCRs (for 35 cycles) were carried out on cDNAs of different human cell lines. OCC-1A/B transcript was detected in SW480, KYSE, AGS, 5637, SK-MEL3, MCF-7, HeLa, HUH-7, K562, U87-MG, and HEK293-T cell lines as well as stem- and progenitor cells such as NT2, Human Cardiomyocytes (HCM1 and 2), and undifferentiated cardiac stem cells (undiff. CSCs). While OCC-1C and $O C C-1 D$ transcripts were detected in several cell lines, they were not expressed in the tested NT-2, HCM, and cardiac stem- or progenitor cell lines (Fig. 2A).

Since preliminary reports attributed a noncoding RNA function to the OCC-1 gene (Pibouin et al. 2002), OCC-1 transcript variants expression status was analyzed in 42 paired tumor and normal colorectal tissues in combination with expression analysis of its neighboring genes located on the $12 q 23.3$ chromosomal region (Fig. 2B). Compared to the normal pairs, the APPL2 gene expression level was significantly down-regulated in the tumors $(P<0.0043)$ (Fig. 2C). In the same pairs, the expression level of the $O C C-1 C$ variant was unchanged in CRC samples. However, the expression level of $O C C-1 A / B$ and $O C C-1 D$ showed $\sim 5$ - and $\sim 12$-fold increase in tumor samples, respectively. Similar to the level of the OCC-1D variant, the $m i R$-exl expression level showed $\sim 12$-fold up-regulation in CRC samples compared to their nontumor paired samples (Fig. 2D). CASC18 showed no expression in CRC and other epithelial tissues, including esophageal, gastric, and bladder tissue sample pairs using real time PCR (data not shown). In order to investigate if miR-ex1 and OCC-1D production is coordinated, their expression pattern was compared in CRC tissues using real time PCR. Results suggested a positive correlation between these RNA variants (Supplemental File S4-4), supporting simultaneous formation of OCC-1D and miR-ex1. Further, the absolute expression level of $O C C-1$ splice variants was measured and represented as "RNA copies per $100 \mathrm{ng}$ of total RNA" in HT-29, HCT116, and SW480 cell lines, representing stages I, II, and IV of CRC, respectively. Real-time analysis of OCC -1 transcript variants in these cell lines indicated no correlation of $O C C-1 C$ expression with $C R C$ staging. However, $O C C-1 A / B$ was increased and $O C C-1 D$ was decreased in the cell lines with higher levels of malignancy (Fig. 2E).

\section{Coding potential of $O C C-1$ transcripts and their effects on fibroblast morphology}

A 63-aa peptide has been recently attributed to the OCC-1A/ $B$ transcript. Sequence analysis of the OCC-1C variant 


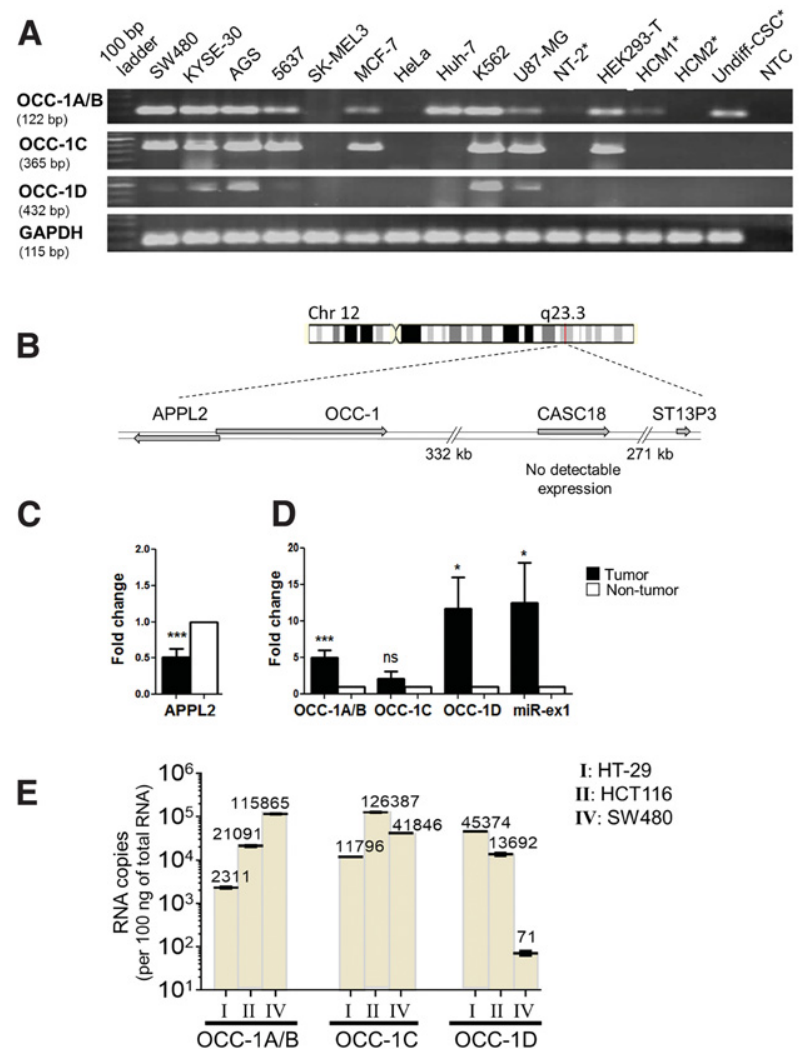

FIGURE 2. Expression analysis of OCC-1 splice variants in different human cell lines and CRC specimens. (A) PCR-amplification of novel $O C C-1$ splice variants in different human cell lines. While $O C C-1 A / B$ and $O C C-1 C$ variants were detectable in the majority of cancer-derived cell lines, OCC-1D was detected in a few cell lines. OCC-1C was not detectable in stem and progenitor cell lines including NT2, HCM1\&2, and $\mathrm{c}-\mathrm{Kit}^{+} \mathrm{CSC}$ (indicated by stars). PCR-amplification on each cDNA sample was run for 35 cycles, and GAPDH was used as an internal control (30 cycle). NTC indicates nontemplate negative control of PCR. (B) Relative position and orientation of APPL2, OCC-1, CASC18, and ST3P3 genes in 12q23.3 region. (C) Transcription level of the APPL2 gene is significantly $(P$-value $<0.0006)$ down-regulated in 42 colorectal tumors compared with the corresponding marginal nontumor tissues, measured by qRT-PCR. $(D)$ Expression changes of OCC-1 splice variants in 42 colorectal tumor samples compared with their marginal, nontumor pairs. Except for the OCC-1C, which exhibited no significant change, $O C C-1 A / B$ and $O C C-1 D$ were up-regulated in colorectal tumors $(\sim 5-$ and $\sim 12$-fold increase, respectively). Similar to OCC- $1 D, m i R-e x 1$ had an $\sim 12$-fold up-regulation in tumor tissues. GAPDH was used as an internal control and each sample was tested in triplicate. Bar graphs indicate the fold change values and bars indicate SEM. (E) Absolute quantification of OCC-1 splice variants expression across HT-29, HCT116, and SW480 cell lines, representing stages I, II, and VI of CRC, respectively. Unlike the $O C C-1 C$ variant, $O C C-1 A / B$ and $O C C$ $1 D$ expressions showed increasing and decreasing patterns as staging was increased.

indicated that $36 \mathrm{nt}$ (corresponding to the $12 \mathrm{aa}$ ) have been eliminated from the middle of the $O C C-1 A / B$ variant without changing the translation frame, and it potentially encodes an unknown 51-aa peptide (Fig. 3A). The coding potential of OCC-1 variants and subcellular localization of related peptides were further analyzed using Flag-tagged constructs, transfected in the SW480 cell line. ICC results indicated that the OCC-1A/B peptide was localized in the nucleus (Fig. 3B; top). OCC-1C seemed capable of producing a novel peptide (GenBank acc. \#: BAM34484.1), which was localized in the cytoplasm of transiently transfected SW480 cells (Fig. 3B; middle).

Overexpression of the Flag-tagged $O C C-1 A / B$ construct resulted in size and number reduction of the transfected fibroblast cells as well as some morphological changes (Fig. 3C; top left). These cells demonstrated increased cell death, detected by flow cytometry (Fig. 3C; top right). The cells that were transfected by the Flag-tagged OCC-1C construct did not show such alterations compared to the cells transfected by scrambled control vector (Fig. 3C; middle and bottom). In all of these experiments, real-time PCR confirmed the overexpression of exogenous $O C C-1 A / B$ and $O C C-1 C$ variants (data not shown). Bioinformatics analysis predicted nuclear localization for the OCC-1A/B peptide but cytoplasmic localization for the $O C C-1 C$ peptide $(\mathrm{S} 3-\mathrm{C})$.

\section{Tumor-specific up-regulation of $O C C-1 A / B$ variant and its cell type-specific survival promotion}

Compared to the results of CRC samples, the transcription level of the $O C C-1 A / B$ variant was measured in 10 paired samples of esophageal, gastric, and bladder tumor tissues (T) versus their marginal nontumor $(\mathrm{N})$ sections. While a distinct up-regulation of the OCC-1A/B transcript was evident in CRC specimens, a significant down-regulation was detected in other cancer types (Fig. 4A). Wnt activity was compared in these cancer types using qRT-PCR against $c$ $M y c$ (as a Wnt pathway target gene [Zhang et al. 2012]), and results indicated the highest transcription level of the $c-M y c$ gene in the CRC specimens (Fig. 4A).

In order to investigate the $O C C-1 A / B$ overexpression effect on the cell cycle progression, OCC-1A/B cDNA was overexpressed in cell lines with different Wnt signaling activity $\left(\mathrm{Wnt}^{-}\right.$and $\left.\mathrm{Wnt}^{+}\right)$. Colorectal originated SW480 $\left(\mathrm{Wnt}^{+}\right)$ and noncolorectal HeLa (Wnt ${ }^{-}$) cells were transiently transfected using the OCC $-1 A / B$ cDNA construct. The cell cycle was promoted in SW480 cells (Fig. 4B), whereas it was arrested in HeLa cells (Fig. 4D) detected by flow cytometry. Consistently, Annexin V/PI results indicated reduced early and late apoptosis rates in the transfected SW480 cells (Fig. 4C) but an increased apoptosis rate in the transfected HeLa cells (Fig. 4E). When Wnt signaling was suppressed in the SW480 cells using XAV939 small molecule $(10 \mu \mathrm{M})$, the cell cycle was arrested (Fig. 4F) and apoptosis rate was increased (Fig. 4G) following the transfection of $O C C-1 A / B$ cDNA in these cells.

Consistently, OCC-1A/B overexpression ended in increased SW480 cell viability but resulted in reduced cell viability in the Wnt ${ }^{-}$HeLa and in the Wnt-suppressed SW480 cells, detected by MTT assay (Fig. 4H). Finally, qRT-PCR expression analysis of the interferon- $\beta$ gene indicated that 
A

OCC-1A/B: MGCGNSTATSAGAGQGPAGAAKDVTEESVTEDDKRRNYGGVYVGLPSEAVNMVSSQTKTVRKN

OCC-1C: MGCGNSTATSAGAGQGPAGAAKDV------------NYGGVYVGLPSEAVNMVSSQTKTVRKN

$\star * * * * * * * * * * * * * * * * * * * * * * *$

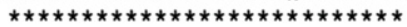

B

SW480

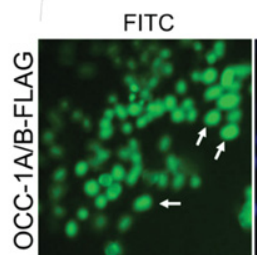

FITC

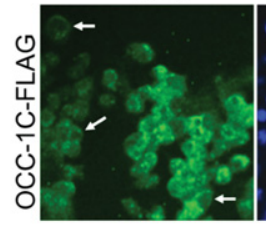

FITC

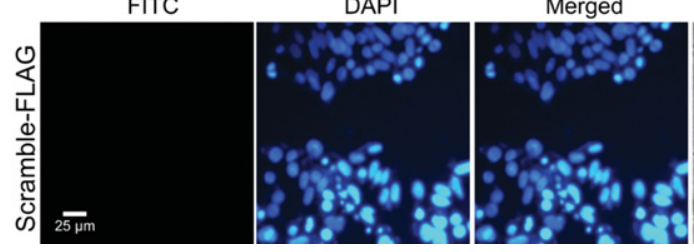

DAPI

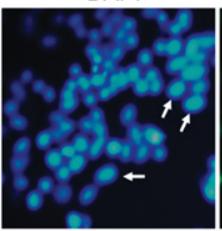

DAPI

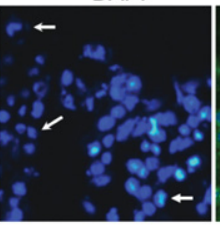

DAPI

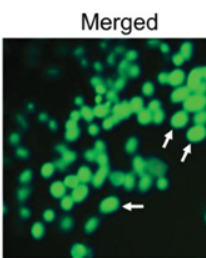

Merged
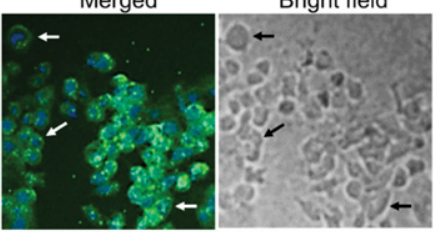

Bright field
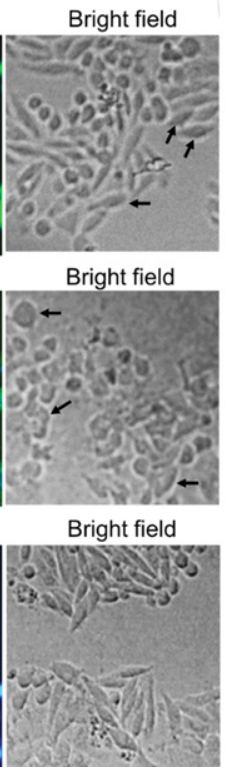

C

fibroblast

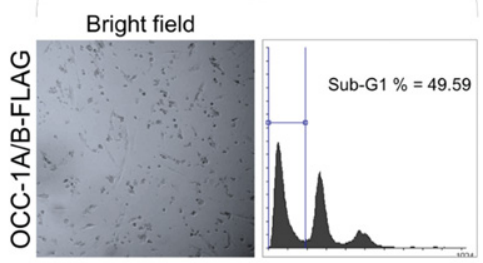

Bright field

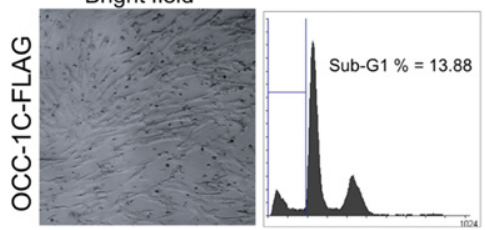

Bright field

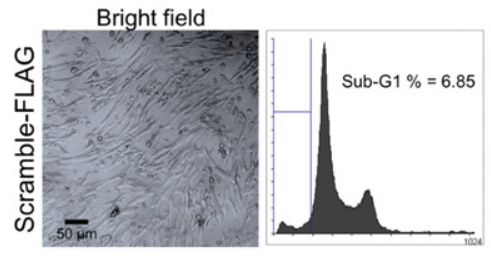

FIGURE 3. Coding potential, subcellular localization, and morphological effects of OCC-1 peptides. (A) Alignment of deduced peptide sequences of $O C C-1 A / B$ and $O C C-1 C$ is shown. A 12 -aa sequence is eliminated from the middle of the OCC-1A/B peptide to produce OCC-1C. (B) Subcellular localization of OCC-1A/B and OCC-1C in transiently transfected SW480 cells detected by ICC technique, using anti-Flag primary antibody and FITCconjugated secondary antibody. While Flag-tagged OCC-1A/B had a concentrated nuclear signal (top), Flag-tagged OCC-1C signal was restricted to the cytoplasm of transiently transfected SW480 cells (middle). Scrambled sequence tagged to the Flag tag had no fluorescent signal (bottom). $(C)$ Fibroblast cells transfected with $O C C-1 A / B, O C C-1 C$, and scrambled vectors showed different morphology, visualized under a contrast field microscope. $(D)$ Flow cytometry on these fibroblast cells suggested cell death induction in the fibroblasts overexpressing the Flag-tagged OCC-1A/B. OCC$1 C$ and scrambled vector had no significant effect on cell cycle.

observed cell death induction in HeLa and Wnt-suppressed SW480 cells has not been due to the interferon response (Supplemental File S6). All data of OCC-1A/B-transfected cells were compared to that of scrambled- and nontransfected controls, and a $P$-value $<0.05$ was considered as a statistical significance level.

\section{Suppressive effect of $O C C-1$ RNA on transcription level of the APPL2 gene provides a putative CRC progression index}

A significant negative correlation $($ Pearson correlation $=$ -0.699; $P$-value $<0.0001)$ was obtained between $O C C-1 A$ / $B$ and APPL2 expression levels in 42 paired CRC specimens (Fig. 5A,B). In some cases, samples with a high level of OCC- $1 A / B$ expression had very low or undetectable APPL2 expression even in 40 cycles of PCR (Pearson correlation = -1.0) (Fig. 5A). The alteration of APPL2 gene expression was further investigated under the $O C C-1 A / B$ protein coding ORF or OCC-1-cDNA overexpression conditions in the SW480 cell line. To this aim, $\sim 300$ bp of $O C C-1 A / B$ upstream sequence corresponding to its ORF and $5^{\prime}$-UTR se- quences was PCR amplified and cloned in the pCMV-Tag4 expression vector (Fig. 5C, fragment a-b). Also, the 1366-bp cDNA sequence of the OCC-1 gene (including its long $3^{\prime}$ UTR) was cloned in the same vector (Fig. 5C, fragment a-c). While overexpression of OCC-1-cDNA strongly suppressed APPL2 transcription, overexpression of its ORF region did not show such an effect (Fig. 5C). Since both constructs shared the a-b sequence, the effects of full-length OCC-1-cDNA on the APPL2 expression level might be attributed to the noncoding segment of this transcript (b-c fragment). Using a complementary antisense RNA against the $O C C-1 A / B$ variant resulted in an increased expression level of the APPL2 gene (Fig. 5C). The effects of these constructs were compared to the scrambled sequence cloned in the same vector (pCMVtag4). A strong negative correlation (Pearson correlation = $-0.828 ; P$-value $<0.0001)$ is calculated between the APPL2 and $O C C-1 A / B$ expression in this experiment (Fig. 5D).

Since OCC-1 and APPL2 negative correlation was supported by several experiments (presented in Figs. 2 and 5), the OCC-1/APPL2 index was deduced from a significant number of tumor samples $(n=28)$ and results were categorized based on the CRC progression (Supplemental File S7). Analysis of 

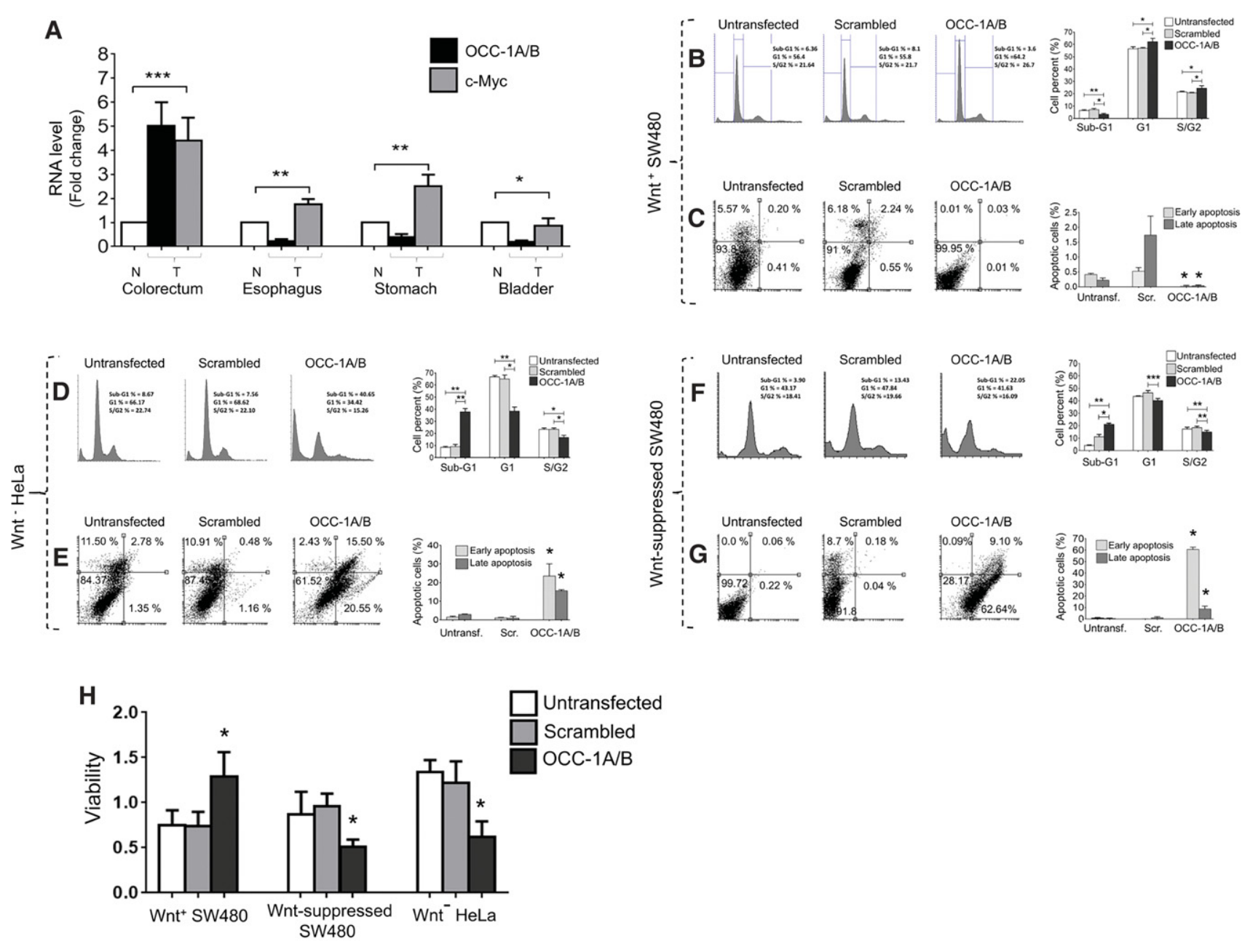

FIGURE 4. CRC-specific up-regulation of OCC-1A/B and its cell-specific effects. ( $A$ ) OCC-1A/B transcription level is compared between CRC specimens (42 pairs) and other epidermal cancers: esophagus, stomach, and bladder (each 10 pairs, $\mathrm{N}=$ nontumor, $\mathrm{T}=$ tumor). The $c-M y c$ expression level is analyzed as a representative gene of Wnt activity. While OCC-1A/B is up-regulated in CRC specimens, it is significantly down-regulated in other tumor types. The expression level in the nontumor pairs is considered one for calculation of fold changes of both OCC-1 and $c-M y c$ genes. (B) Flow cytometry results of the SW480 cell line (contains active Wnt signaling shown by $\mathrm{Wnt}^{+}$), transfected by the OCC-1A/B variant, compared to the scrambled- and untransfected SW480 cells as controls. Quantified flow cytometry result is shown as a percentage of the cells in sub-G1\%, G1\%, and S/G2\% phases. Cell cycle is promoted in SW480 cells overexpressing OCC-1A/B (shown by reduction of sub-G1 cell population and increase of the cells in G1 and S/G2 phases). (C) Annexin V/PI test in SW480 cells transfected by OCC-1A/B is compared to the controls. Cell percentage of each phase is indicated in all diagrams as the mean of triplicates. Consistent with flow cytometry data, quantitative analysis of the Annexin V/PI results showed a reduced apoptosis rate in $\mathrm{Wnt}^{+} \mathrm{SW} 480$ cells, overexpressing the $O C C-1 A / B$ variant. $(D)$ OCC-1A/B overexpression in HeLa cells $\left(\mathrm{Wnt}^{-}\right.$) has resulted in cell death (unlike in Wnt ${ }^{+} \mathrm{SW} 480$ cells), shown by flow cytometry. Quantified result shows increased number of sub-G1 cells and decrease of G1 and S/G2 cells populations. (E) Increased early and late apoptosis rate in HeLa cells is shown through Annexin V/PI test as a result of OCC-1A/B overexpression, consistent with part $D$. $(F, G)$ Overexpression of $O C C-1 A / B$ in Wnt-suppressed SW480 cells (Wnt signaling is suppressed using XAV939 small molecule) is compared to the controls, and the effect is shown by flow cytometry $(F)$ and Annexin V/PI test $(G)$. Overexpression of OCC-1A/B has resulted in increased sub-G1 cell population and reduction of the cells in G1 and S/G2 phases $(F)$. Early and late apoptosis have also been increased in these cells $(G) .(H)$ MTT assay indicated that unlike in HeLa $\left(\mathrm{Wnt}^{-}\right)$and in Wnt-suppressed SW480 cells, SW480 cells $\left(\mathrm{Wnt}^{+}\right)$had a higher viability rate following the overexpression of $O C C-1 \mathrm{~A} / B$ compared to the corresponding controls. $\left.{ }^{* * *}\right) P$-values $<$ 0.001; (**) $P$-values $<0.01$; $\left(^{*}\right) P$-values $<0.05$.

the categorized data indicated a high positive correlation between the OCC-1/APPL2 index and the higher stages of CRC.

\section{Linking the OCC-1 gene to the Wnt signaling pathway}

The OCC- $1 A / B$ and $m i R$-ex 1 functional effect on Wnt signaling was further investigated using diverse experimental pro- cedures. In comparison with the scrambled-transfected cells, OCC-1A/B-ORF overexpression led to the Wnt signaling upregulation, detected by TOP/FOPflash assay. However, OCC$1 A / B$-cDNA construct overexpression led to the Wnt signaling attenuation (Fig. 6A). In order to discriminate the coding and noncoding RNA functions of the OCC-1 gene against Wnt signaling, mutated OCC-1-cDNA (harboring ATG $\rightarrow$ 
A

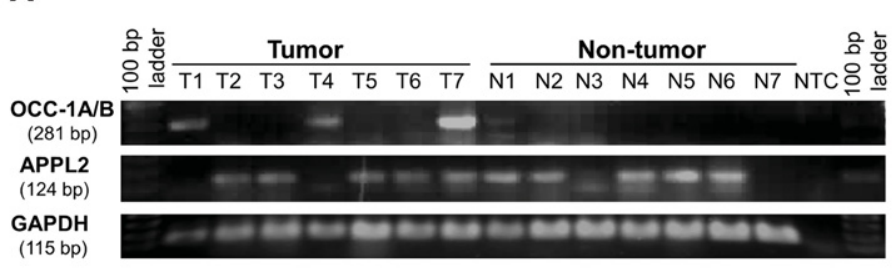

C

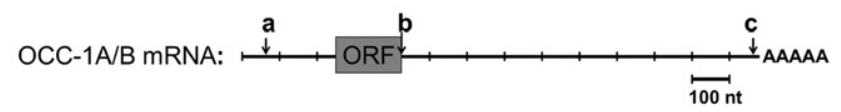

APPL2 expression level

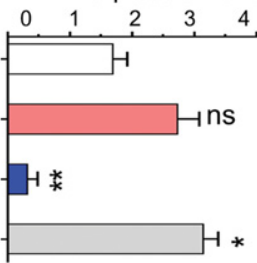

B

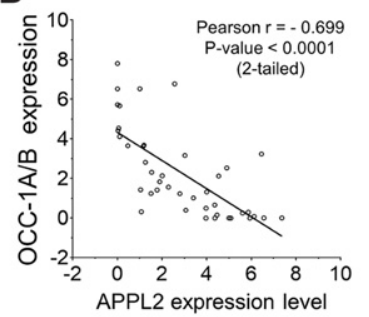

D

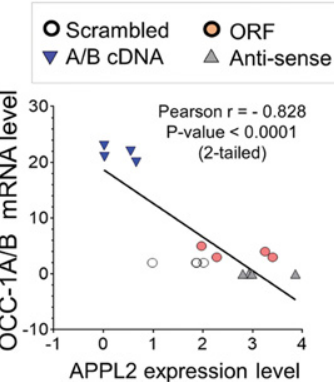

FIGURE 5. OCC-1 noncoding RNA function against neighboring APPL2 gene expression. (A) Electrophoresis gel image demonstrates remarkable negative correlation between the expression of $O C C-1 A / B$ and $A P P L 2$ in seven paired samples of colorectal tumor $(\mathrm{T})$ and nontumor $(\mathrm{N})$ tissues. $(B)$ Significant negative correlation between the expression level of the OCC-1A/B variant and the APPL2 gene in 42 CRC samples. (C) Shows APPL2 transcription level under the different states of OCC-1A/B expression in SW480 cells, detected through qRT-PCR in three independent experiments. Overexpression of the ORF portion of OCC-1A/B did not significantly alter the APPL2 transcription level, compared to the scrambled control. Overexpression of OCC-1 full-length cDNA resulted in significant suppression of APPL2 expression (shown as blue bar), suggesting the regulatory effect of OCC-1A/B $3^{\prime}$-UTR. Overexpression of $O C C-1 A / B$ antisense resulted in significant up-regulation of APPL2 gene transcription. (D) Representative correlation between OCC-1A/B full-length RNA and APPL2 transcription level, deduced from part $C$.

CTG mutation) was also transfected in SW480 cells. The Wnt signaling pathway was strongly suppressed in these cells compared to the scrambled control (Fig. 6A). The Wnt signaling up-regulation effect of OCC-1A/B-ORF overexpression was further supported via qRT-PCR against Cyclin-D1 and $c$ $M y c$ genes which are targeted by this pathway (Fig. 6B).

In comparison with the mock-transfected cells, miR-exI overexpression led to Wnt signaling up-regulation, and miR-exl down-regulation led to Wnt signaling suppression, detected by TOP/FOPflash assay (Fig. 6C). The Wnt signaling up-regulation effect of miR-exl overexpression was further supported via qRT-PCR against $C y c l i n-D 1$ and $c-M y c$ genes (Fig. 6D). Cotransfection of OCC-1A/B-ORF or miR-ex1 with FOPflash construct did not change the luciferase expression in these experiments. Results of the TOP/FOPflash assay are presented as the ratio of the TOP over FOP luciferase signals.

The APC2 gene with a pivotal role in the Wnt pathway was predicted as the main target gene for miR-exl (Supplemental File S5). Moreover, RT-PCR analysis indicated that miR-ex1 overexpression caused APC2 mRNA level reduction (Fig. $6 \mathrm{E})$. The MiR-ex-1 overexpression effect on the APC2 protein was also investigated through ELISA. Compared to the multiple controls, results indicated that the APC2 protein level has been reduced following miR-exl overexpression in
SW480 cells. Consistently, miR-ex1 down-regulation resulted in subtle (nonsignificant) APC2 protein level elevation (Fig. $6 \mathrm{~F})$. Direct interaction of miR-ex1 and APC2 transcripts was also investigated through cloning of APC2 3 '-UTR sequence downstream from the luciferase ORF. Compared to controls, luciferase activity was significantly down-regulated in the cells overexpressing $m i R$-exl, supporting the direct interaction of miR-exl with the $3^{\prime}$-UTR sequence of APC2. Neither overexpression nor down-regulation of $m i R-e x 1$ affected the luciferase activity level of a construct made of luciferase ORF fused to the nontarget TrkC $3^{\prime}$-UTR sequence (Fig. $6 \mathrm{G})$. According to flow cytometry data, overexpression of $O C C-1 A / B$ or $m i R$-exl constructs induced cell cycle progression, while down-regulation of $O C C-1 A / B$ or $m i R$-exl caused an elevation in the proportion of cells in the sub-G1 stage (Fig. $6 \mathrm{H}, \mathrm{J})$. Consistently, OCC-1A/B-ORF or miR-exl overexpression led to the increased cell viability of transfected cells, detected by MTT assay (Fig. 6I,K).

\section{DISCUSSION}

The Wnt signaling pathway is the most altered signaling pathway in CRC (Bienz and Clevers 2000; Colussi et al. 2013). The human locus $12 q 23.3$ is enriched for cancer-related genes including APPL2, OCC-1, CASC18, and ST13P3. APPL2 is 
A

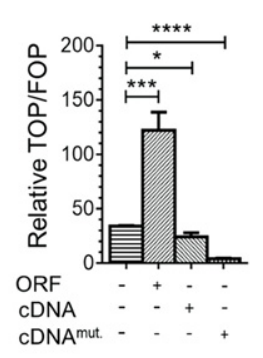

B

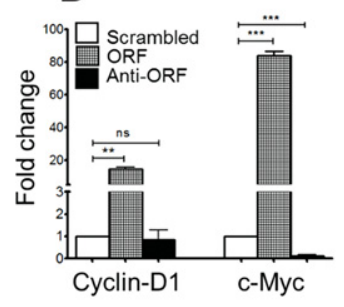

C

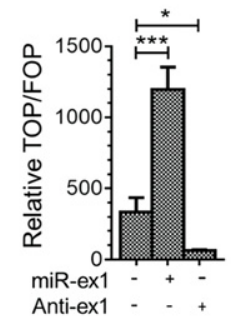

D

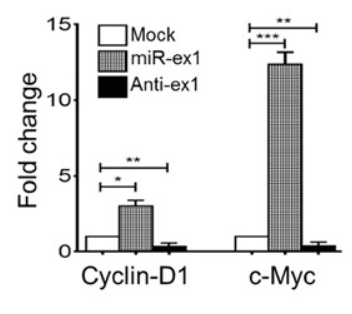

E

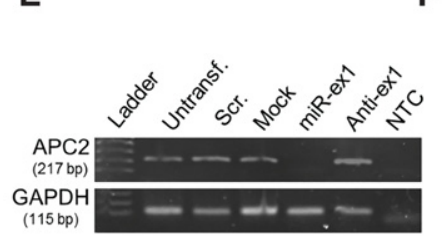

F

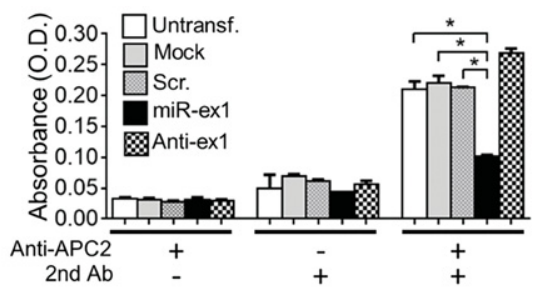

G

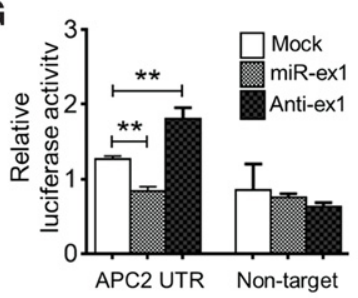

H

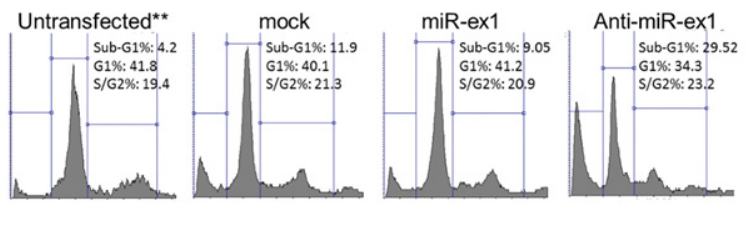

J

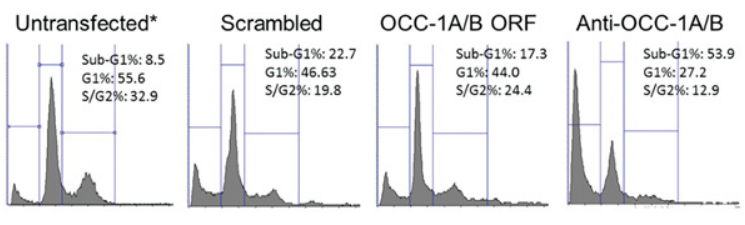

I

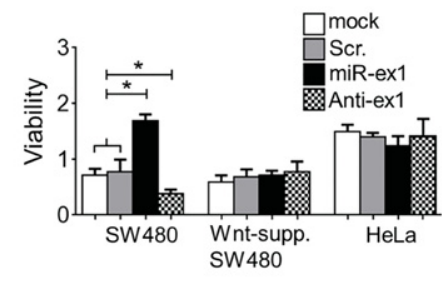

K

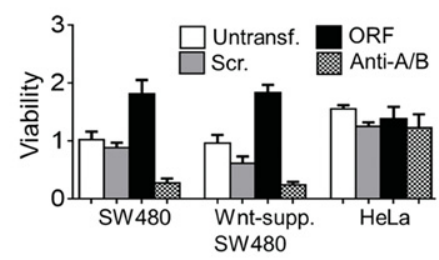

FIGURE 6. Evidence for the involvement of the OCC-1 gene in the Wnt signaling pathway. (A) Shows TOP/FOPflash assay results following the overexpression of OCC-1A/B-ORF, -cDNA, and -CDNA ${ }^{\text {mut }}$ (impaired at ATG site of ORF) in SW480 cells. Results indicated that the OCC-1-encoded peptide enhanced while its noncoding RNA function reduced the Wnt activity. Results are compared to the scrambled-transfected cells. (B) QRT-PCR against Wnt pathway downstream genes (Cyclin-D1 and $c-M y c)$ confirmed the positive effect of the OCC-1A/B encoded peptide on Wnt activity. $O C C-1 A / B$-ORF overexpression resulted in increased Cyclin-D1 and $c$-Myc expression levels while its down-regulation (using anti-ORF) had a reverse effect. $(C, D)$ MiR-exl overexpression resulted in Wnt signaling up-regulation, whereas its knockdown resulted in decreased Wnt activity, shown by TOP/FOPflash assay in SW480 cells $(C)$. This result was confirmed by qRT-PCR against Cyclin-D1 and $c$-Myctranscripts $(D)$. (E) RT-PCR result showed APC2 down-regulation following the miR-ex1 overexpression (lane 5). (F) ELISA results indicated APC2 protein level reduction following the miR-exl overexpression in SW480 cells. (G) Dual luciferase assay supported direct interaction of miR-ex1 with APC2 $3^{\prime}$-UTR sequence. Specific targeting of the APC2-3'-UTR sequence by miR-ex1 was confirmed when TrkC 3'-UTR (as nontarget) was used instead of the APC2 $3^{\prime}$-UTR sequence. $(H)$ Shows miR-exl expression alteration effect on the cell cycle progression, measured by flow cytometry. MiR-exl overexpression resulted in subtle reduction of the sub-G1 cell population, consistent with the remarkable opposite effect of anti-miR-ex1. (I) Shows miR-exl expression alteration effect on the cell viability, measured by MTT assay. MiR-exl overexpression resulted in increased cell viability in $\mathrm{Wnt}^{+}$cells (SW480), unlike in $\mathrm{Wnt}^{-}$cells (Wnt suppressed SW480 and HeLa cells). $J$ ) Shows OCC-1A/B-ORF expression alteration effect on the cell cycle progression, measured by flow cytometry. OCC-1A/B-ORF overexpression resulted in reduction of the sub-G1 cell population, consistent with the remarkable opposite effect of anti-OCC-1A/B-ORF. $(K)$ Shows OCC-1A/B-ORF expression alteration effect on the cell viability, measured by MTT assay. OCC-1A/B-ORF overexpression increased cell viability in SW480 and Wnt-suppressed SW480 cells, without any effect in HeLa cells. $\left.{ }^{* * *}\right) P$-values $<0.001 ;\left(^{* *}\right) P$-values $<0.01 ;(*) P$-values $<0.05$.

interactive with the Deleted in Colorectal Carcinoma (DCC) gene (Liu et al. 2002) and is considered a positive regulator of the Wnt signaling pathway (Cleasby et al. 2011). OCC-1 has been considered a differentially up-regulated gene in CRC (Pibouin et al. 2002), and ST13P3 is a pseudogene of the CRC-related gene ST13 (Sossey-Alaoui et al. 2002). 
Here, we intended to investigate the association of $12 q 23.3$ locus and CRC through functional analysis of OCC-1 novel transcripts against Wnt signaling pathway components.

The OCC- 1 gene is reported to be transcribed in two highly similar transcript variants such that here we assigned them as an $O C C-1 A / B$ variant. Here for the first time, two novel splice variants of the OCC-1 gene assigned as OCC-1C, OCC-1D, and a novel miRNA named miR-exl are introduced (Fig. 1). OCC-1 was initially reported as a noncoding RNA gene (Pibouin et al. 2002); however, it (OCC-1A/B variant) encodes a protein called $A G D 3$ with an attributed role in the differentiation of adipocytes (Kikuchi et al. 2009). Later, it was reported that the AGD3 protein is expressed in several areas of rat brain and binds to the insulin receptor substrate 4 (IRS4) protein, promoting insulin signaling (Chai et al. 2013).

OCC-1C lacks an internal $36 \mathrm{nt}(12 \mathrm{aa})$ at the middle of the AGD3 protein coding ORF (Figs. 1B, 3A). In another event, the AUG start codon of the gene has been spliced out to create an OCC-1D noncoding RNA variant (Fig. 1B). A spliced out short RNA segment had most of the miRNA precursor features (Krol et al. 2004), including a 60-nt-long hairpin secondary structure and saddle-like conservation pattern (Fig. 1D,E). Therefore, production of an OCC-1-originated miRNA was investigated following a protocol we have used for other miRNA discoveries (Parsi et al. 2012; Dokanehiifard et al. 2015; Saleh et al. 2016). Briefly, the predicted miRNA precursor and its mature form $(m i R-e x 1)$ were PCR amplified from a cDNA library of U87 cell lines (Supplemental File S4-3). Then, sequencing of the amplification products indicated that at least a 19-nt-long miR-ex1-5p has been produced in this cell line (Fig. 1F). Recently, RNAseq databases have introduced $m i R-e x 1-3 p$, which supports our findings (Supplemental File S2-3).

The $O C C-1 A / B$ variant was expressed in different cell lines; however, OCC-1C and OCC-1D variants were not detected in the tested stem or progenitor cell lines (Fig. 2A). It remains to be tested if these variants are involved in stemness of the cells. These results also indicate that novel OCC-1 transcripts are not aberrant transcripts, which often are produced during cancer progression (Venables 2004; Ostler et al. 2007; Fackenthal and Godley 2008).

Expression changes of OCC-1D and miR-ex 1 in CRC specimens were about three times more than that of $O C C-1 A / B$ (Fig. 2D), which candidated these variants as distinct markers for CRC progression with potential clinical application. Bioinformatics analysis predicted a coding ORF for the OCC-1 gene that is known to encode AGD3 protein (Kikuchi et al. 2009). Deduced protein sequence alignment indicated that 12 aa have been deleted from the middle of this ORF to form the OCC-1C peptide (Fig. 3A). Distinguished detection of OCC-1A/B and OCC-1C peptides using immunostaining is laborious due to their small size and high similarity of amino acid sequences. Therefore, their coding potential and subcellular localization were investigated using exogenous expression of Flag-tagged $O C C-1 A / B$ or OCC-1C sequences, followed by an ICC experiment and using monoclonal antibody against the tag (Fig. 3B). As a result, SW480 cells expressing Flag-tagged OCC-1A/B showed a concentrated nuclear fluorescent signal for $O C C-1 A / B$ encoded peptide, while an OCC-1C-related signal was localized in the cytoplasm of transfected SW480 cells (Fig. 3B). Consistent with our results, the PSORTII bioinformatics tool predicted nuclear and cytoplasmic localization of OCC1A/B and OCC-1C peptides, respectively (Supplemental File S3-C). Nevertheless, the Protein Atlas database (http://www. proteinatlas.org/search/agd3) has reported both nuclear, cytoplasm, and cell membrane localization for the AGD3 protein (Supplemental File S3-B) without taking into account the presence of an OCC-1C encoded peptide. Also, challenging our results, others have used a polyclonal antibody for detection of an endogenously expressed AGD3 homolog in rat brain cells and reported its cytoplasmic localization (Chai et al. 2013). Since OCC-1A/B and OCC-1C peptides are small and they only differ by 12 aa, the use of a polyclonal antibody may explain our different results.

Furthermore, unlike the $O C C-1 C, O C C-1 A / B$ overexpression resulted in morphological alteration of transfected fibroblast cells (Fig. 3C; left). Nuclear localization of the OCC-1A/ $B$ peptide proposed a regulatory effect for this peptide which motivated us to follow its effect on the biology of the cell.

The OCC-1A/B transcription level is increased in the CRC samples but is decreased in other tested epithelial cancers compared to normal paired samples (Fig. 4A). A similar effect has been reported for some other genes such as TGF- $\beta$, which is down-regulated in gastric (Li et al. 2002) and upregulated in other cancers (Derynck et al. 2001; Lebrun 2012) including CRC (Shen et al. 2014). This CRC-specific effect was further supported by flow cytometry results of OCC $-1 A / B$ cDNA overexpression; while $O C C-1 A / B$ overexpression promoted the cell cycle in SW480 $\left(\mathrm{Wnt}^{+} \mathrm{CRC}\right.$-originated cell line), it increased the cell death rate in HeLa (Wnt ${ }^{-}$) and Wnt-suppressed SW480 cell lines (Fig. 4B-G).

Transfection of OCC-1A/B-cDNA in Wnt-suppressed SW480 cell lines resulted in induction of early and late apoptosis in these cells (Fig. 4G). To investigate if such an induced apoptosis rate is specific to $O C C-1 A / B$ but not the interferon responses (Reynolds et al. 2006), we analyzed the expression of the interferon- $\beta$ (IFN- $\beta$ ) gene, which is associated with apoptosis (Chawla-Sarkar et al. 2001). Results indicated that IFN- $\beta$ remained unchanged during all transfection procedures (Supplemental File S6), implying that detected apoptosis is associated with $O C C-1 A / B$ expression in these cells. The mechanism(s) of the distinctive OCC-1A/B apoptotic effect in $\mathrm{Wnt}^{-}$cells remains to be investigated. Consistently, TOP/FOPflash luciferase assay (Roose et al. 1998) indicated that $O C C-1 A / B$ variant overexpression has resulted in increased Wnt signaling activity in the SW480 cell line (Fig. 6A). This result emphasized the colorectal-specific regulatory role of the $O C C-1 A / B$ variant. Wnt signaling 
activation caused by $O C C-1 A / B$ overexpression and a high level of $O C C-1 A / B$ expression in CRC samples proposed it as a novel CRC-specific oncogene.

OCC-1A/B ORF encompasses only $14 \%$ of the 1366 -ntlong transcript and the rest is noncoding. On the other hand, noncoding RNAs may modulate the neighboring gene expression in cis or trans (Guttman and Rinn 2012). Therefore, the OCC- $1 D$ variant and also the OCC- $1 A / B$ long UTR sequence may affect the flanking genes' expression. Real time analysis of $O C C-1$ variants and their neighboring genes in CRC specimens showed a strong negative correlation between $O C C-1 A / B$ and APPL2 gene expression level (Figs. $2 \mathrm{D}, 5 \mathrm{~A}, \mathrm{~B})$. Neighboring coexpressed genes often share regulatory elements (Xu et al. 1997; Gherman et al. 2009). However, no such element was detected for these two genes. In order to investigate if the OCC-1A/B peptide, alone or along with its long noncoding $3^{\prime}$-UTR, is responsible for the negative correlation with the APPL2 gene, corresponding sequences of $O C C-1 A / B$ were cloned and overexpressed in the SW480 cell line in a gain of function strategy. Results indicated that $O C C-1 A / B 3^{\prime}-\mathrm{UTR}$ is responsible for the observed negative correlation (Fig. 5C,D). Regardless of the mechanism(s), APPL2 down-regulation under the overexpression of OCC- 1 cDNA suggests that OCC-1 noncoding RNA may function as an upstream regulator of APPL2 gene expression. Similar effects on nearby genes are now reported for many other noncoding RNA genes (Wilusz et al. 2009). When OCC-1A/B ORF (without $3^{\prime}$-UTR) and OCC-1A/B full-length cDNA (having $3^{\prime}$-UTR) were equally transfected in SW480 cells, real-time PCR detected a higher level of $O C C-1 A / B$ ORF RNA than that of OCC-1A/B full-length cDNA. Transfection of a full-length cDNA with impaired ATG start codon resembled the results of wild-type cDNA transfection (Supplemental File S10). $3^{\prime}$-UTR in OCC-1A/B is encoded by two exons that are unified through splicing out of the last intron. Such transcripts are rare and would normally be expected to undergo nonsense-mediated mRNA decay (Mendell et al. 2004) that may justify a lower level of $O C C-1 A / B$ full-length cDNA. According to the observed negative correlation, a CRC progression index was deduced between the OCC-1A/B and APPL2 genes' expression levels, which could be used as an indicator of CRC progression with potential clinical application (Supplemental File S7). The highest level of this ratio is specific to stage 4 of CRC in which OCC-1 is overexpressed while APPL2 transcripts are not detectable. It remains to be tested if down-regulation of OCC-1 or up-regulation of APPL2 is capable of suppressing CRC.

While OCC-1 versus APPL2 expression level (Fig. 5; Supplemental File S7) provided a strong CRC progression index, it still does not associate the 12q23.3 human chromosome locus to CRC. More direct evidence came from our discovery of OCC-1-originated miR-exl, which was capable of targeting APC2 transcripts (Fig. 6E-G). MiR-ex1 or OCC$1 A / B$ overexpression resulted in promotion of Wnt signaling,

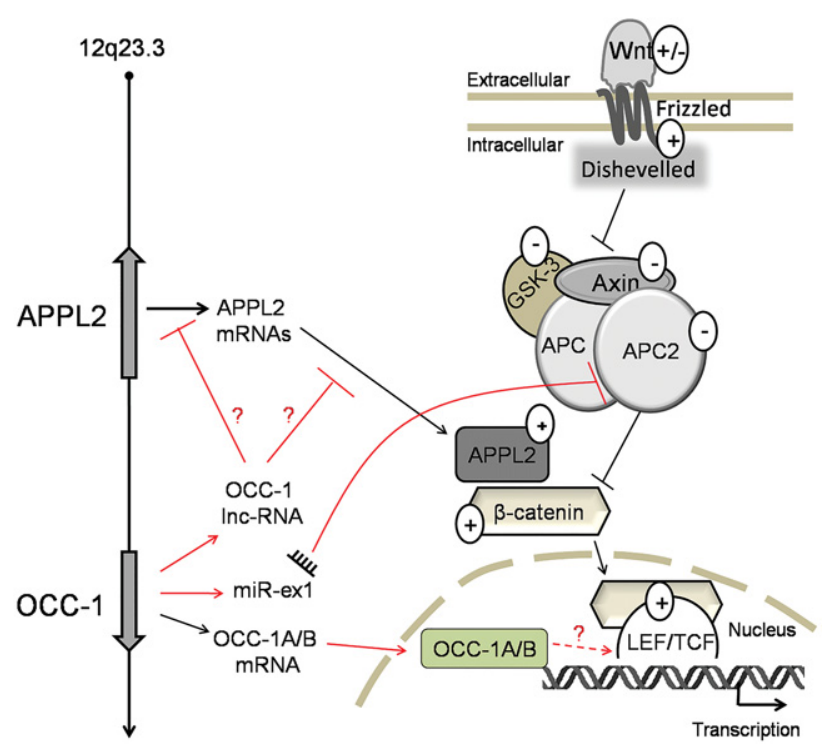

FIGURE 7. Suggested model for modulation of Wnt pathway by OCC-1 splice variants. An elaborated Wnt signaling model is suggested based on the literature and the current results, which incorporates the OCC1 gene in this pathway. The OCC-1A/B activator peptide and OCC-1originated miR-exl both result in up-regulation of the Wnt signaling pathway in this model. Attenuation of the Wnt signaling pathway is also attributed to the noncoding RNA function of the OCC-1 gene. The latter function is suggested to be exerted through suppression of the OCC-1 neighboring gene (APPL2) at the transcriptional level. The findings of this study are shown as red lines, and black lines denote the previously known interactions.

and consistently their knockdown attenuated this pathway (Fig. 6A-D). Furthermore, their knockdown resulted in increased cell death (Fig. 6H,J). Taken together, OCC-1-originated transcripts (Fig. 1) in a cell type-specific fashion (Fig. 4) can modulate the Wnt signaling pathway (Fig. 6) directly through targeting of $A P C 2$ transcripts or other nuclear components of the Wnt signaling pathway (Fig. 3), or indirectly through regulation of APPL2 gene expression (Fig. 5).

Accordingly, here a model is suggested that functionally links human chromosome 12q23.3 colocated OCC-1 and APPL2 genes together and also to the Wnt signaling pathway (Fig. 7). Since the OCC-1A/B peptide is localized to the nucleus (Fig. 3) and its overexpression resulted in Wnt signaling up-regulation (Fig. 6), it may activate Wnt signaling through TCF activation, which is shown as a dashed arrow in the model, denoting an unknown mechanism (Fig. 7). While APPL2 is a positive regulator of the Wnt signaling pathway (Rashid et al. 2009), its transcription is suppressed by a OCC-1 noncoding RNA portion by an unknown mechanism (Fig. 5C), shown by a solid red line and question marks (Fig 7). That may justify when $O C C-1 A / B$ full-length $c D N A$ is overexpressed in the SW480 cell line; its noncoding RNA function attenuates Wnt signaling up-regulation, which is induced by OCC-1A/B coding function (Fig. 6A). Noncoding RNA function of the OCC-1 gene is more highlighted 
when only the ATG start codon of the gene is point-mutated and its suppression effect on Wnt signaling is stronger than wild-type OCC-1 cDNA sequence (Fig. 6A). That means that $O C C-1$ up-regulates the Wnt signaling pathway through both its nuclear localized peptide (Fig. 3) and also through production of $m i R$-exl (Figs. 1, 6), which is shown by red arrows in the model (Fig. 7). Overall, the Wnt signaling pathway is extended in our model by introducing OCC-1 as a new regulator.

\section{MATERIALS AND METHODS}

\section{Bioinformatics}

Order, distance, and orientation of the genes located on chromosome 12q23.3 were surveyed by the Entrez gene NCBI database. NCBI Mapviewer was used to find ESTs existing in the studied chromosomal region. The conservation status was evaluated in the UCSC Genome Browser (Kent et al. 2002). The latest version of the GENCODE database (version 25) was used to determine the last updated information of C12orf75 gene structure and its transcript variants. NCBI-ORF Finder was used to find ORFs in the RNA sequences. Deduced amino acid sequences from each ORF were submitted to InterProScan (Zdobnov and Apweiler 2001) for existence of any conserved protein domains and PSORTII (Horton et al. 2007) for cellular localization prediction. Multiple sequence alignment was performed by NCBI-BLAST and ClustalW (Larkin et al. 2007). RNA-Fold (Zuker and Stiegler 1981; Zuker 1989) and Mfold (Zuker 2003) were used to predict the RNA secondary structure and its stability. The PHDcleave website was used for the prediction of mature miRNA based on predicted Dicer sites (Ahmed et al. 2013). MiRNA target prediction was performed by DIANA microT v3.0 (Maragkakis et al. 2009) and validated by RNAhybrid software (Rehmsmeier et al. 2004; Krüger and Rehmsmeier 2006) and miRmap (Vejnar and Zdobnov 2012). Searching in RNA-sequencing data was performed by using NCBI-SRA and NCBI-GEO to examine the existence of our novel discovered transcripts in long and small RNA-sequencing data.

\section{Colorectal tissue samples}

Colorectal samples were obtained from patients who had been referred to the Digestive Disease Research Institute (DDRI)-Shariati Hospital-Tehran-Iran, at the time of surgical resection. For each sample, the tumor section was paired with the adjacent normal section in separate cryotubes. The samples were then immediately snap-frozen in liquid nitrogen and stored at $-80^{\circ} \mathrm{C}$ until use. The pathology of tumor samples was confirmed and collected with written consent from each patient. This study was approved by the Clinical Research Ethics Committee of Shariati Hospital, Tehran University of Medical Sciences.

\section{Plasmid construction}

To determine subcellular localization of $O C C-1 A / B$ and $O C C-1 C$ peptides, their ORF sequences were fused to the Flag nucleotide sequence, which natively exists in a pCMV-tag4 vector (Agilent Technologies). To this end, corresponding ORFs were amplified from cDNA of colon tissue and separately inserted between Sac1 and Sal1 sites of the pCMV-tag4 vector in a frame with the Flag epitope sequence. The resultant constructs encode C-terminal Flagtagged peptides containing 63 (for OCC-1A/B) and 51 (for OCC1C) aa, tagged by 8 aa of Flag. The full-length cDNA of OCC-1 was amplified and cloned into pCMV-tag4 between the sites of BamH1 and EcoRV in order to analyze the putative function of OCC $-1 A / B$ mRNA in noncoding form. ATG-mutant OCC $-1 A / B$ full-length cDNA was made through site-directed mutagenesis using SOEing PCR, which converted ATG to CTG. The feature of noncanonical processing of $m i R$-exl, given in our experiment, compelled us to use the shRNA system by $\mathrm{pRNA}-\mathrm{H}_{1.1}$ vector (Genscript) for overexpression of $m i R-e x 1$ in human cell lines. In this method, a fragment containing an exact 60-nt stem-loop structure of premiR-ex1 followed by a transcription terminator was annealed, PCR-amplified, and inserted between BamH1 and HindIII sites under the transcription of the pol-III H1 promoter. This construct is named pRNA- $\mathrm{H}_{1.1} / \mathrm{miR}$-ex1. In parallel, two control vectors were prepared; one of them has no insert $\left(\mathrm{pRNAH}_{1.1} / \mathrm{empty}\right.$ or mock) and another contains an irrelevant sequence that forms a miRNAlike hairpin structure and does not have any homology to human transcriptome or genome. For other types of vectors, a scrambled vector containing a nonfunctional insert has been considered. All plasmid constructs were confirmed by colony PCR and sequencing.

An APC2 gene 3'-UTR sequence (481-2551 nt from the start of $3^{\prime}$-UTR) containing five of six putative $m i R$-ex 1 binding sites was PCR amplified and inserted into the psiCHECK2 vector (Promega). The XhoI/Not1 site immediately downstream from the stop codon of Renilla luciferase was utilized, resulting in generation of a psiCHECK2 recombinant vector containing Luciferase::APC23'-UTR construct. A sequence with similar size (TrkC $3^{\prime}$-UTR), which had no predicted MRE for miR-exl, was also cloned in the psiCHECK2 vector, and then it was used as the nontarget control.

For TOP/FOPflash reporter assays, pGL4.14 (luc2/Hygro) vector (Promega) was modified to TOPflash by adding three copies of the TCF-LEF response element along with a minimal TK promoter. For the FOPflash construct, the three copies of the TCF-LEF response element in TOPflash were replaced by mutant sequences.

\section{Antisense down-regulation}

Introduction of a complementary RNA and formation of double strand RNAs induces both a potent and specific gene silencing effect (Bosher and Labouesse 2000). Therefore, antisense constructs for down-regulation of long RNAs were prepared by cloning of a reverse-complement sequence of related RNAs in the same vector type that was selected to express the sense RNA sequences. For down-regulation of $m i R$-exl, complementary oligonucleotides (Table 1, row 16) containing both antisense and sense strands sequences (ensuring a loop in between) were annealed together and cloned into the pRNA- $\mathrm{H}_{1.1}$ vector under the control of the $\mathrm{H}_{1}$ promoter using BamH1 and HindIII restriction sites. To validate the efficacy of down-regulation, qRT-PCR was carried out for intended transcripts by comparing their expression levels in antisense-transfected cells with mock- or scrambled-transfected cells as controls.

\section{Cell culture and transfection}

The human colorectal adenocarcinoma cell line, SW480, and the squamous cell carcinoma, KYSE-30, were grown in Roswell Park 
TABLE 1. Sequences and features for primers that were used in this study

\begin{tabular}{|c|c|c|}
\hline$\#$ & Description & Sequence $\left(5^{\prime}>3^{\prime}\right)$ \\
\hline \multirow[t]{2}{*}{1} & Amplification of OCC- 1 full cDNA and & TTGGAATTCCСCСАCTCGGTTCCTGG \\
\hline & cloning in pCMV-tag4 & 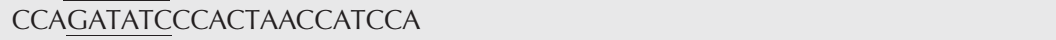 \\
\hline \multirow[t]{2}{*}{2} & OCC -1 nested primers for variant & 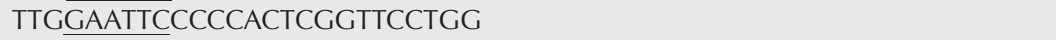 \\
\hline & isolation $\left(R_{\mathrm{taa}}\right)$ & TATCAGCTGACTTGTCTTTCGTAGGTGGCC \\
\hline \multirow[t]{2}{*}{3} & Amplification of OCC-1A/B and OCC-1C ORF & TTGGAATTCGCCCTTCGTCTCGGTCTCC \\
\hline & and cloning into pCMV-tag4 & 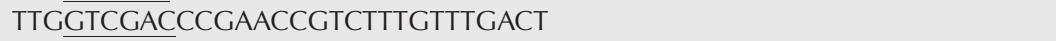 \\
\hline \multirow[t]{2}{*}{4} & GAPDH (real time PCR) & GCCACATCGCTCAGACAC \\
\hline & & GGCAACAATATCCACTTTACCAG \\
\hline \multirow[t]{2}{*}{5} & OCC-1A/B (real time PCR) & CCGGCCGGCTGCGCGATGG \\
\hline & & СТССТСТTGTCАTСТTСТGTTACGG \\
\hline \multirow[t]{2}{*}{6} & OCC-1C (real time PCR) & GGAGCAGCCAAAGATGTAAACTATGG \\
\hline & & TATCAGCTGACTTGTCTTTCGTAGGTGGCC \\
\hline \multirow[t]{2}{*}{7} & OCC-1D (real time PCR) & AGAGCTCCGGAGCGCGGGCC \\
\hline & & TATCAGCTGACTTGTCTTTCGTAGGTGGCC \\
\hline \multirow[t]{2}{*}{8} & APPL2 (real time PCR) & TTCTTCACCCAAGGCGGGAAT \\
\hline & & GGAAGCAGTAGCGCCGGTCTT \\
\hline \multirow[t]{2}{*}{9} & ST13P3 (real time PCR) & TTCTGCACACCGAGGAAATGCAT \\
\hline & & СТGССТTTAАGTСТTССТССАССС \\
\hline \multirow[t]{2}{*}{10} & APC2 (real time PCR) & CGCCACCCGTGAGGACTACAGGC \\
\hline & & GATCATCTTGTGCTTGGAGTGCACC \\
\hline \multirow[t]{2}{*}{11} & CASC18 EST, AK001551.1 & GССССТTСТССТСТССТСАСТGG \\
\hline & & TCAGTTATCTGCATTCATCTGTCTC \\
\hline \multirow[t]{2}{*}{12} & CASC18 EST, DA023900.1 & GCСССTGGGATTGTTCTG \\
\hline & & TCAGTTATCTGCATTCATCTGTCTC \\
\hline \multirow[t]{2}{*}{13} & Cyclin-D1 (real time PCR) & CAGAGTGATCAAGTGTGACCC \\
\hline & & CGTCGGTGGGTGTGCAAGC \\
\hline \multirow[t]{2}{*}{14} & c-Myc (real-time PCR) & СTCCTACGTTGCGGTCACAC \\
\hline & & CGGGTCGCAGATGAAACTCT \\
\hline \multirow[t]{2}{*}{15} & IFN- $\beta 1$ (real-time PCR) & CTAGCACTGGCTGGAATGAG \\
\hline & & ССТСССАТААТАТСТTTTCAG \\
\hline \multirow[t]{2}{*}{16} & Cloning of anti-miR-ex1 in pRNA- $\mathrm{H}_{1.1}$ & cgcGGATCCCCGCGCCCGCGCTGGTGGCGGTGGAGTTCCCGCAGCCC \\
\hline & & ссCAAGCTTttcсаaаaаaCTTCCCCGGCCGGCTGCGCGATGGGCTGCGGGAAC \\
\hline \multirow[t]{2}{*}{17} & Cloning of APC2 $3^{\prime}$-UTR & accgCTCGAGGGGCGAAGCCTGTAATCACTGC \\
\hline & & ataagaatGCGGCCGCGAGTCGGACAGCTGACGGTG \\
\hline \multirow[t]{2}{*}{18} & Cloning of TrkC $3^{\prime}$-UTR & CTCGAGAGACCTGTGGAGGTTGGATTGGG \\
\hline & & GCGGCCGCATTGCAGAGCCCAGAGCAGGG \\
\hline \multirow[t]{2}{*}{19} & Cloning of pre-miR-ex 1 in pRNA- $\mathrm{H}_{1.1}$ & cgcGGATCCCTTCCСCGGCCGGСTGCGCGATGGGCTGCGGGAACTCCAC \\
\hline & & СCСAAGCTTTTCCAAAAAACCGCGCCCGCGCTGGTGGCGGTGGAGTTCCCGCAG \\
\hline \multirow[t]{2}{*}{20} & Minimal promoter in pGL4.14 & AGATCTAGAGGGTATATAATGGAAGC \\
\hline & & 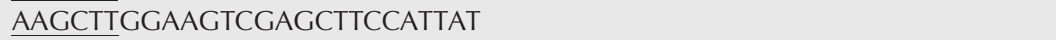 \\
\hline \multirow[t]{2}{*}{21} & Cloning of TOP $(3 \times)$ sequence in pGL4.14 & AAGATCAAAGGGGGTAAGATCAAAGGGGGTAAGATCAAAGGGggAGATCAAAGGG \\
\hline & & AGATCTCССТTTGATCTTAAGСССТTTGATСТTAAАСССТTTСАТСТССССС \\
\hline 22 & Anchored oligo(dT) for cDNA synthesis & GCGTCGACTAGTACAACTCAAGGTTCTTCCAGTCACGACGTTTTTTTTTTTTTTTTTTTT[N] \\
\hline \multirow[t]{4}{*}{23} & Detecting and quantification of the miR-ex 1 & miR-ex1-F1 CCGGCCGGCTGCGCGATGG \\
\hline & & miR-ex1-F2 CCGGCCGGCTGCGCGAT \\
\hline & & Universal-R outer GCGTCGACTAGTACAACTCAAG \\
\hline & & Universal-R inner $_{\text {AACTCAAGGTTCTTCCAGTCACG }}$ \\
\hline \multirow[t]{2}{*}{24} & U48 (real-time PCR) & U48-Forward TGACCCCAGGTAACTCTGAGTGTGT \\
\hline & & 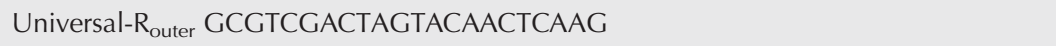 \\
\hline
\end{tabular}

Underlined nucleotides are digestion sites of restriction enzymes.

Memorial Institute (RPMI)-1640 medium (Gibco). Cell lines, including Fibroblast (HFSF-PI3), AGS, 5637, SK-MEL-3, MCF-7, Hela, Huh7, K562, U87-MG, NT2, and HEK293-T were maintained in Dulbecco's modified Eagle's medium (DMEM) (Gibco). Human cardiomyocytes (HCM) and cardiac stem cells (CaSC) were obtained from the Royan Stem Cell Bank (National code number: RSCB1080) approved by the ethical committees of the Royan Stem Cell Bank. These cells were cultured in Iscove's modified
Dulbecco's medium (IMDM) (Gibco). All media were supplemented with $10 \%$ heat-inactivated fetal bovine serum, $2 \mathrm{mM} \mathrm{L}$-glutamine, and $1 \%$ antibiotics $(100 \mathrm{U} / \mathrm{mL}$ of penicillin and $100 \mu \mathrm{g} / \mathrm{mL}$ of streptomycin) (Gibco). Cells were grown at $37^{\circ} \mathrm{C}$ in a humidified atmosphere of $5 \% \mathrm{CO}_{2}$. Transfections in cell lines were performed using Lipofectamine 2000 (Invitrogen) following the manufacturer's instructions (Dalby et al. 2004). Forty-eight hours after transfection, the transfection efficiency was measured by fluorescence 
microscopy, and the overexpression was analyzed by qRT-PCR. The overexpression and efficient processing of mature miR-ex 1 in cell lines was confirmed by real-time PCR, and the specificity was verified by TA-cloning and sequencing.

\section{RNA extraction and cDNA synthesis}

Total RNA from frozen tissues or harvested cell lines was extracted using TRIzol reagent (Invitrogen) in accordance with the manufacturer's instructions. RNA integrity and concentration were determined by standard RNA gel electrophoresis and spectrophotometry at $260 \mathrm{~nm}$. The total RNA was treated with RNase-free DNase (Fermentas) and used for cDNA synthesis using anchored-oligo $(\mathrm{dT})_{18}$ primer (Table 1) and RevertAid TM MMuLV Reverse Transcriptase (Fermentas) in a $20 \mu \mathrm{L}$ reaction according to the manufacturer's instructions. For each sample, a No-RT control was used in parallel.

\section{Primer sequences and features}

The appropriate PCR primers were designed using Primer3 software (http://frodo.wi.mit.edu/primer3/) and analyzed by OligoAnalyser from IDT (http://eu.idtdna.com/site) and Gunrunner software (version 3.02; Hastings Software), and their sequences for several purposes are represented in Table 1.

\section{Reverse transcription-PCR (RT-PCR) and real-time PCR (qRT-PCR)}

RT-PCR was performed using $1 \mu \mathrm{L}$ of cDNA template with pre-mix Taq polymerase (Solis BioDyne) and $0.4 \mu \mathrm{M}$ of each primer in a 25 $\mu \mathrm{L}$ PCR reaction. Quantitative real-time PCR was performed using the SYBR Premix Ex Taq Kit (Takara Biotechnology) on an ABI 7500 Detection System (Applied Biosystems). CDNA corresponding to $50 \mathrm{ng}$ of RNA was added to the SYBR Premix Ex Taq Kit $(0.2 \mu \mathrm{M}$ of each specific primer, $10 \mu \mathrm{L}$ of SYBR-Green Taq Ready Mix) in a total reaction volume of $20 \mu \mathrm{L}$. The threshold cycle $\left(C_{\mathrm{t}}\right)$ for individual reactions was identified using ABI 7500 detection system software. Relative genes' expression was calculated with the $2^{-\mathrm{ddCt}}$ method (Livak and Schmittgen 2001). For each individual realtime PCR, a final melting curve analysis was considered to ensure the specificity of PCR products. Specific primers for real time PCR individually were similar to RT-PCR primers (Table 1). The RNA copy numbers of $O C C-1 A / B, O C C-1 C$, and $O C C-1 D$ variants were determined based on the standard curves prepared from known serial dilution of vectors, containing these variants and interpolation of their PCR signal on cDNA samples $\left(C_{t}\right)$ into corresponding standard curves (Illumina protocol:(http://www. illumina.com/Documents/products/technotes/technote_eco_absolute_ quantification_using_sybrgreen.pdf) (Nolan et al. 2006; Cui et al. 2007; Lefever et al. 2009).

\section{Isolation and sequencing of $O C C-1$ variants}

For cloning of OCC-1 and its overexpression in cell lines, two specific primers for the $5^{\prime}$ and $3^{\prime}$ ends of OCC-1 mRNA (GenBank accession number: NM_001145199) were designed. To exclude any nonspecific PCR products, a nested PCR was done on the diluted
PCR products. The result was three bands on the agarose gel that were ligated into the pTG19T-cloning vector (Vivantis, Malaysia) and sequenced.

For detection of miR-exl a protocol adopted from Parsi et al. (2012) was used. Briefly, RNA preparation was polyadenylated in order to add a poly(A) tail to miRNAs, and cDNA was synthesized using anchored oligo(dT) primer. Then PCR was carried out using $m i R$-exl specific primer, and anchor-specific primer and products were cloned in the TA vector for sequencing and deduction of miR-ex1 sequence.

\section{Immunocytochemistry (ICC)}

SW480 cells were cultured in a 24 -well plate $\left(8 \times 10^{4}\right.$ cells/well $)$ and transiently transfected by constructs $(1 \mu \mathrm{g} /$ well of DNA and $1.5 \mu \mathrm{L}$ of Lipofectamine 2000) encoding Flag-tagged OCC-1A/B and OCC1C peptides under the condition of G418 $(1.2 \mu \mathrm{g} / \mathrm{mL}$ medium; Invitrogen) antibiotic treatment. Forty-eight hours post-transfection, SW480 cells were washed with phosphate buffered saline (PBS) and fixed for $15 \mathrm{~min}$ at room temperature in 4\% paraformaldehyde (PFA) in PBS. The cells were washed twice with ice-cold PBS and permeabilized with PBS containing $0.2 \%$ Triton X-100 for $10 \mathrm{~min}$ at $4^{\circ} \mathrm{C}$. After washing the cells in PBS three times (each wash for $5 \mathrm{~min}$ ), a blocking solution containing PBS and 10\% bovine serum was applied for $1 \mathrm{~h}$ at room temperature. Afterward, the primary antibody (rat monoclonal anti-Flag; 1:1000, Agilent Technologies) diluted in a blocking solution was treated overnight at $4^{\circ} \mathrm{C}$. After three washes in PBS, the FITC-conjugated secondary antibody (anti-rat IgG [1:32], Sigma) was diluted in a blocking solution and added for $1 \mathrm{~h}$ at room temperature in the dark. The secondary antibody solution was decanted and washed three times with PBS for 5 min each in the dark. Finally, the cells were incubated for $5 \mathrm{~min}$ with $0.1 \mu \mathrm{g} / \mathrm{mL}$ DAPI as a nuclear counter-stain. The cells were viewed using an inverted fluorescence microscope (OLYMPUS IX53). Image overlays and contrast enhancement were performed using Adobe Photoshop 7.0 ME software.

\section{Enzyme-linked immunosorbent assay (ELISA)}

For measurement of APC2 protein levels under the miR-ex 1 expression alteration, SW480 cells were plated in a six-well plate $\left(4.8 \times 10^{5}\right.$ cells/well), and $24 \mathrm{~h}$ later were transfected by mock-, scramble-, $m i R$-ex1-, and anti-miR-ex1-containing constructs ( $4 \mu \mathrm{g}$ of plasmid and $5.5 \mu \mathrm{L}$ of lipofectamin in each well). Forty-eight hours posttransfection, protein extracts were obtained by lysing cells in RIPA lysis buffer (Abcam) and $1 \mathrm{mM}$ PMSF ( $\mathrm{pH} 7.4$ ), followed by centrifugation in $10,000 \mathrm{rpm}$ and $4^{\circ} \mathrm{C}$ for $5 \mathrm{~min}$. Thereafter, a 96-well ELISA plate was coated with equal amounts of extracted total protein $(100 \mu \mathrm{L} /$ well $)$ and washed three times with $300 \mu \mathrm{L} /$ well wash buffer (PBS containing $0.05 \%$ [v/v] Tween-20; Sigma). Nonspecific binding was blocked with addition of $250 \mu \mathrm{L} /$ well of $1 \% \mathrm{BSA}$ in PBS for $2 \mathrm{~h}$ at $37^{\circ} \mathrm{C}$. The plate was washed three times and incubated with anti-APC2 primary antibody (1:1000) (Abcam; ab113370) followed by detection of horseradish peroxidase-conjugated secondary antibody solution (1:2000) (Abcam; ab97057). After the addition of $100 \mu \mathrm{L} /$ well of the peroxidase substrate TMB (Sigma) in $0.05 \mathrm{~mol} / \mathrm{L}$ phosphate-citrate buffer containing $0.014 \% \mathrm{H}_{2} \mathrm{O}_{2}(\mathrm{pH}=5.0)$ (Sigma), color development was allowed to proceed for 5-15 min and was terminated by the addition 
of $100 \mu \mathrm{L} /$ well of $4 \mathrm{~N} \mathrm{H}_{2} \mathrm{SO}_{4}$. The absorbance was measured at 490 $\mathrm{nm}$ in an ELISA Microplate Reader (Biotek). Data of each sample is the mean of triplicates.

\section{Cell cycle analysis}

Cells $\left(1.2 \times 10^{5}\right.$ cells/well for SW480 and $1 \times 10^{5}$ cells/well for HeLa cells) were transfected in 24-well plates in triplicate. For each construct, a scrambled vector $(1 \mu \mathrm{g} /$ well $)$ along with untransfected cells were used as negative controls. Thirty-six hours after transfection, floating and adherent cells were harvested, combined, and processed. The supernatant from each well was combined with the cells harvested from each well by trypsinization. The cells were collected by centrifugation (at $1600 \mathrm{rpm}$ for $5 \mathrm{~min}$ in $4^{\circ} \mathrm{C}$ ), fixed with ice-cold $70 \%$ ethanol, washed with PBS, and resuspended in $0.5 \mathrm{~mL}$ of PBS containing propidium iodide $(1 \mathrm{mg} / \mathrm{mL})$ and RNase A $(0.20 \% \mathrm{v} / \mathrm{v})$. After a final incubation at $37^{\circ} \mathrm{C}$ for $30 \mathrm{~min}$, cells were analyzed using a FACS Calibur flow cytometer (Becton Dickinson). A total of 10,000 events were counted for each sample. Data were analyzed using Flowing Software version 2.5.

\section{Flow cytometric assessment of apoptosis using annexin $\mathrm{V}$ assay}

SW480 and HeLa cells (plated $1.2 \times 10^{5}$ and $1 \times 10^{5}$ cells per well, respectively) were transfected in 24 -well plates in triplicate. For each construct, a scrambled vector $(1 \mu \mathrm{g} /$ well $)$ along with untransfected cells were used as negative controls. Thirty-six hours after transfection, floating and adherent cells were harvested, combined, and stained by using a commercially available Annexin-V-FLUOS Staining Kit (Roche, cat. no. 11858777001) according to the manufacturer's instructions. Then the stained cells were analyzed using a FACS Calibur flow cytometer (Becton Dickinson). Approximately 10,000 counts were made for each sample. The percentage distributions of apoptotic cells were calculated using Flowing Software, version 2.5.

\section{Dual-luciferase assay}

To validate the direct interaction of $m i R$-exl with the APC2 gene 3'-UTR, HEK293-T cells were cotransfected with psiCHECK-2/ APC2-3'-UTR vector (200 ng/well) and miRNA-expressing vector (pRNA-H ${ }_{1.1} / \mathrm{miR}_{\text {-ex1 }}$ ) (400 ng/well) in 48-well plates. As negative controls, scrambled and empty pRNA- $\mathrm{H}_{1.1}$ vectors were used in cotransfection. For each experimental trial, wells were transfected in triplicate, and each well was assayed in triplicate. For each well, luciferase activity was measured $48 \mathrm{~h}$ after transfection using the Dual Luciferase Reporter Assay System (Promega) as per the manufacturer's instructions.

\section{TOPflash reporter assay}

TOP/FOP reporter assays were carried out with the Dual-Glo Luciferase System (Promega) in a 48-well plate, following the manufacturer's instructions. Briefly, TOPflash or FOPflash constructs (200 ng/well) were transiently cotransfected into SW480 cells together with appropriate constructs and a scrambled vector (400 ng/well) in triplicate. Forty-eight hours later, TOPflash was mea- sured for each vector. None of the constructs significantly affected FOPflash values. The experiment was repeated twice and resulted in the same data.

\section{Cell proliferation (MTT) assay}

HeLa and SW480 cells (7000 and 9000 cells/well, respectively) were plated in a 96-well plate in triplicate. After $24 \mathrm{~h}$, they were transfected by lipofectamine $2000(0.30 \mu \mathrm{L} /$ well $)$ and vectors $(0.25 \mu \mathrm{g} /$ well $)$. Forty-eight hours post-transfection, $10 \mu \mathrm{L}$ of $5 \mathrm{mg} / \mathrm{mL}$ MTT (Sigma) was added to each well, followed by further culture for $4 \mathrm{~h}$, after which the culture medium was discarded. To each well, $150 \mu \mathrm{L}$ DMSO (Sigma) was added and the wells were mixed by shaking in the dark. OD490 was measured with an ELISA Microplate Reader (Biotek) after the crystals dissolved. The formula: rate of growth in cancer cells $=($ average OD490 in test groups/average OD490 in control groups) $\times 100 \%$.

\section{Statistical analysis}

The levels of $\Delta \Delta \mathrm{C}_{\mathrm{t}}$ between cancer tissues and noncancerous tissues were analyzed by the paired Student's $t$-test to determine statistical significance by the probability of difference between the means. $P$ $<0.05$ was considered statistically significant. Values in all the graphs are expressed as means \pm SEM. For each experiment, the significance of differences between groups or samples was determined by comparison test (GraphPad Prism 6: GraphPad Software). Correlation analysis was also performed using GraphPad Prism software, represented as a Pearson coefficient.

\section{SUPPLEMENTAL MATERIAL}

Supplemental material is available for this article.

\section{ACKNOWLEDGMENTS}

We thank Dr. Masoud Soleimani, Maryam Kay, and Ali Jason Saleh for their kind advice and technical assistance including immonocytochemistry and fluorescent imaging. This work has been supported by financial assistance from TMU and the Iran National Science Foundation (INSF; grant number 94012136).

Author contributions: H.N., B.M.S., and S.J.M. conceived and designed the study and wrote the paper. H.N., S.D., and B.M.S. performed experiments and analyzed the results. S.N. provided cancer tissue samples with preparation of pathological features. All authors reviewed the results and approved the final version of the manuscript.

Received February 12, 2016; accepted October 10, 2016.

\section{REFERENCES}

Ahmed F, Kaundal R, Raghava GP. 2013. PHDcleav: a SVM based method for predicting human Dicer cleavage sites using sequence and secondary structure of miRNA precursors. BMC Bioinformatics 14: 1 .

Bienz M, Clevers H. 2000. Linking colorectal cancer to Wnt signaling. Cell 103: 311-320.

Bosher JM, Labouesse M. 2000. RNA interference: genetic wand and genetic watchdog. Nat Cell Biol 2: E31-E36. 
The Cancer Genome Atlas Network. 2012. Comprehensive molecular characterization of human colon and rectal cancer. Nature 487: 330-337.

Chai B, Li JY, Fritze D, Zhang W, Xia Z, Mulholland MW. 2013. A novel transcript is up-regulated by fasting in the hypothalamus and enhances insulin signalling. J Neuroendocrinol 25: 292-301.

Chawla-Sarkar M, Leaman DW, Borden EC. 2001. Preferential induction of apoptosis by interferon (IFN)- $\beta$ compared with IFN- $\alpha 2$ correlation with TRAIL/Apo2L induction in melanoma cell lines. Clin Cancer Res 7: 1821-1831.

Cleasby ME, Lau Q, Polkinghorne E, Patel SA, Leslie SJ, Turner N, Cooney G, Xu A, Kraegen E. 2011. The adaptor protein APPL1 increases glycogen accumulation in rat skeletal muscle through activation of the PI3-kinase signalling pathway. J Endocrinol 210: 81-92.

Colussi D, Brandi G, Bazzoli F, Ricciardiello L. 2013. Molecular pathways involved in colorectal cancer: implications for disease behavior and prevention. Int J Mol Sci 14: 16365-16385.

Cui W, Taub DD, Gardner K. 2007. qPrimerDepot: a primer database for quantitative real time PCR. Nucleic Acids Res 35: D805-D809.

Dalby B, Cates S, Harris A, Ohki EC, Tilkins ML, Price PJ, Ciccarone VC. 2004. Advanced transfection with Lipofectamine 2000 reagent: primary neurons, siRNA, and high-throughput applications. Methods 33: 95-103.

Derrien T, Johnson R, Bussotti G, Tanzer A, Djebali S, Tilgner H, Guernec G, Martin D, Merkel A, Knowles DG. 2012. The GENCODE v7 catalog of human long noncoding RNAs: analysis of their gene structure, evolution, and expression. Genome Res 22: 1775-1789.

Derynck R, Akhurst RJ, Balmain A. 2001. TGF- $\beta$ signaling in tumor suppression and cancer progression. Nat Genet 29: 117-129.

Dokanehiifard S, Soltani BM, Parsi S, Hosseini F, Javan M, Mowla SJ. 2015. Experimental verification of a conserved intronic microRNA located in the human TrkC gene with a cell type-dependent apoptotic function. Cell Mol Life Sci 72: 1-13.

Fackenthal JD, Godley LA. 2008. Aberrant RNA splicing and its functional consequences in cancer cells. Dis Model Mech 1: 37-42.

Gherman A, Wang R, Avramopoulos D. 2009. Orientation, distance, regulation and function of neighbouring genes. Hum Genet 3: 143.

Guttman M, Rinn JL. 2012. Modular regulatory principles of large noncoding RNAs. Nature 482: 339-346.

Horton P, Park K-J, Obayashi T, Fujita N, Harada H, Adams-Collier C, Nakai K. 2007. WoLF PSORT: protein localization predictor. Nucleic Acids Res 35: W585-W587.

Huang H, He X. 2008. Wnt/ $\beta$-catenin signaling: new (and old) players and new insights. Curr Opin Cell Biol 20: 119-125.

Jemal A, Bray F, Center MM, Ferlay J, Ward E, Forman D. 2011. Global cancer statistics. CA Cancer J Clin 61: 69-90.

Kent WJ, Sugnet CW, Furey TS, Roskin KM, Pringle TH, Zahler AM, Haussler D. 2002. The Human Genome Browser at UCSC. Genome Res 12: 996-1006.

Kikuchi K, Fukuda M, Ito T, Inoue M, Yokoi T, Chiku S, Mitsuyama T, Asai K, Hirose T, Aizawa Y. 2009. Transcripts of unknown function in multiple-signaling pathways involved in human stem cell differentiation. Nucleic Acids Res 37: 4987-5000.

Krol J, Sobczak K, Wilczynska U, Drath M, Jasinska A, Kaczynska D, Krzyzosiak WJ. 2004. Structural features of microRNA (miRNA) precursors and their relevance to miRNA biogenesis and small interfering RNA/short hairpin RNA design. J Biol Chem 279: 4223042239.

Krüger J, Rehmsmeier M. 2006. RNAhybrid: microRNA target prediction easy, fast and flexible. Nucleic Acids Res 34: W451-W454.

Larkin M, Blackshields G, Brown N, Chenna R, McGettigan PA, McWilliam H, Valentin F, Wallace IM, Wilm A, Lopez R. 2007. Clustal W and Clustal X version 2.0. Bioinformatics 23: 2947-2948.

Lebrun J-J. 2012. The dual role of TGF in human cancer: from tumor suppression to cancer metastasis. Int Sch Res Not 2012: 1-28.
Lefever S, Vandesompele J, Speleman F, Pattyn F. 2009. RTPrimerDB: the portal for real-time PCR primers and probes. Nucleic Acids Res 37: D942-D945.

Li QL, Ito K, Sakakura C, Fukamachi H, Inoue KI, Chi XZ, Lee KY, Nomura S, Lee CW, Han SB. 2002. Causal relationship between the loss of RUNX3 expression and gastric cancer. Cell 109: 113-124.

Lichtenstein P, Holm NV, Verkasalo PK, Iliadou A, Kaprio J, Koskenvuo M, Pukkala E, Skytthe A, Hemminki K. 2000. Environmental and heritable factors in the causation of canceranalyses of cohorts of twins from Sweden, Denmark, and Finland. N Engl J Med 343: 78-85.

Liu J, Yao F, Wu R, Morgan M, Thorburn A, Finley RL, Chen YQ. 2002. Mediation of the DCC apoptotic signal by DIP13a. J Biol Chem 277: 26281-26285.

Livak KJ, Schmittgen TD. 2001. Analysis of relative gene expression data using real-time quantitative PCR and the $2^{-\Delta \Delta C}$ method. Methods 25: 402-408.

Lustig B, Behrens J. 2003. The Wnt signaling pathway and its role in tumor development. J Cancer Res Clin Oncol 129: 199-221.

Maragkakis M, Reczko M, Simossis VA, Alexiou P, Papadopoulos GL, Dalamagas T, Giannopoulos G, Goumas G, Koukis E, Kourtis K. 2009. DIANA-microT web server: elucidating microRNA functions through target prediction. Nucleic Acids Res 37: W273-W276.

Mendell JT, Sharifi NA, Meyers JL, Martinez-Murillo F, Dietz HC. 2004. Nonsense surveillance regulates expression of diverse classes of mammalian transcripts and mutes genomic noise. Nat genet 36: 1073-1078.

Miaczynska M, Christoforidis S, Giner A, Shevchenko A, UttenweilerJoseph S, Habermann B, Wilm M, Parton RG, Zerial M. 2004. APPL proteins link Rab5 to nuclear signal transduction via an endosomal compartment. Cell 116: 445-456.

Nolan T, Hands RE, Bustin SA. 2006. Quantification of mRNA using real-time RT-PCR. Nat Protoc 1: 1559-1582.

Ostler K, Davis E, Payne S, Gosalia B, Exposito-Cespedes J, Le Beau M, Godley L. 2007. Cancer cells express aberrant DNMT3B transcripts encoding truncated proteins. Oncogene 26: 5553-5563.

Parsi S, Soltani BM, Hosseini E, Tousi SE, Mowla SJ. 2012. Experimental verification of a predicted intronic microRNA in human NGFR gene with a potential pro-apoptotic function. PLoS One 7: e35561.

Pibouin L, Villaudy J, Ferbus D, Muleris M, Prospéri MT, Remvikos Y, Goubin G. 2002. Cloning of the mRNA of overexpression in colon carcinoma-1: a sequence overexpressed in a subset of colon carcinomas. Cancer Genet Cytogenet 133: 55-60.

Rashid S, Pilecka I, Torun A, Olchowik M, Bielinska B, Miaczynska M. 2009. Endosomal adaptor proteins APPL1 and APPL2 are novel activators of $\beta$-catenin/TCF-mediated transcription. J Biol Chem 284: 18115-18128.

Rehmsmeier M, Steffen P, Höchsmann M, Giegerich R. 2004. Fast and effective prediction of microRNA/target duplexes. RNA 10: 15071517.

Reynolds A, Anderson EM, Vermeulen A, Fedorov Y, Robinson K, Leake D, Karpilow J, Marshall WS, Khvorova A. 2006. Induction of the interferon response by siRNA is cell type- and duplex length-dependent. RNA 12: 988-993.

Roose J, Molenaar M, Peterson J, Hurenkamp J, Brantjes H, Moerer P, van de Wetering M, Destrée O, Clevers H. 1998. The Xenopus Wnt effector XTcf-3 interacts with Groucho-related transcriptional repressors. Nature 395: 608-612.

Saleh AJ, Soltani BM, Dokanehiifard S, Medlej A, Tavalaei M, Mowla SJ. 2016. Experimental verification of a predicted novel microRNA located in human PIK3CA gene with a potential oncogenic function in colorectal cancer. Tumor Biol: 1-13.

Schenck A, Goto-Silva L, Collinet C, Rhinn M, Giner A, Habermann B, Brand M, Zerial M. 2008. The endosomal protein Appl1 mediates Akt substrate specificity and cell survival in vertebrate development. Cell 133: 486-497. 
Schlosshauer PW, Pirog EC, Levine RL, Ellenson LH. 2000. Mutational analysis of the CTNNB1 and APC genes in uterine endometrioid carcinoma. Mod Pathol 13: 1066-1071.

Segditsas S, Tomlinson I. 2006. Colorectal cancer and genetic alterations in the Wnt pathway. Oncogene 25: 7531-7537.

Shen L, Qu X, Ma Y, Zheng J, Chu D, Liu B, Li X, Wang M, Xu C, Liu N. 2014. Tumor suppressor NDRG2 tips the balance of oncogenic TGF- $\beta$ via EMT inhibition in colorectal cancer. Oncogenesis 3: e86.

Sossey-Alaoui K, Kitamura E, Head K, Cowell JK. 2002. Characterization of FAM10A4, a member of the ST13 tumor suppressor gene family that maps to the $13 \mathrm{q} 14$. 3 region associated with B-Cell leukemia, multiple myeloma, and prostate cancer. Genomics 80: $5-7$.

Vejnar CE, Zdobnov EM. 2012. MiRmap: comprehensive prediction of microRNA target repression strength. Nucleic Acids Res 40: 1167311683.

Venables JP. 2004. Aberrant and alternative splicing in cancer. Cancer Res 64: 7647-7654.
Wilusz JE, Sunwoo H, Spector DL. 2009. Long noncoding RNAs: functional surprises from the RNA world. Genes Dev 23: 1494-1504.

Xu C-F, Chambers JA, Solomon E. 1997. Complex regulation of the BRCA1 gene. J Biol Chem 272: 20994-20997.

Zdobnov EM, Apweiler R. 2001. InterProScan-an integration platform for the signature-recognition methods in InterPro. Bioinformatics 17: 847-848.

Zhang S, Li Y, Wu Y, Shi K, Bing L, Hao J. 2012. Wnt/ $\beta$-catenin signaling pathway up-regulates c-Myc expression to promote cell proliferation of P19 teratocarcinoma cells. Anat Rec 295: 2104-2113.

Zuker M. 1989. Computer prediction of RNA structure. Methods Enzymol 180: 262-288.

Zuker M. 2003. Mfold web server for nucleic acid folding and hybridization prediction. Nucleic Acids Res 31: 3406-3415.

Zuker M, Stiegler P. 1981. Optimal computer folding of large RNA sequences using thermodynamics and auxiliary information. Nucleic Acids Res 9: 133-148. 

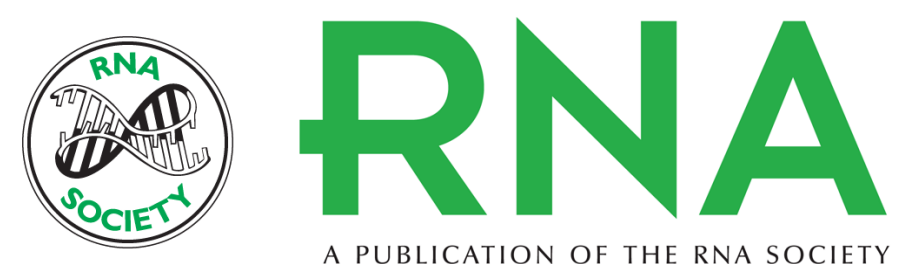

A PUBLICATION OF THE RNA SOCIETY

\section{Alternative splicing of the $O C C-1$ gene generates three splice variants and a novel exonic microRNA, which regulate the Wnt signaling pathway}

Hadi Najafi, Bahram M. Soltani, Sadat Dokanehiifard, et al.

RNA 2017 23: 70-85 originally published online October 21, 2016

Access the most recent version at doi:10.1261/rna.056317.116

Supplemental Material

References

Creative Commons License

Email Alerting Service
http://rnajournal.cshlp.org/content/suppl/2016/10/21/rna.056317.116.DC1

This article cites 56 articles, 13 of which can be accessed free at: http://rnajournal.cshlp.org/content/23/1/70.full.html\#ref-list-1

This article is distributed exclusively by the RNA Society for the first 12 months after the full-issue publication date (see http://rnajournal.cshlp.org/site/misc/terms.xhtml). After 12 months, it is available under a Creative Commons License (Attribution-NonCommercial 4.0 International), as described at http://creativecommons.org/licenses/by-nc/4.0/.

Receive free email alerts when new articles cite this article - sign up in the box at the top right corner of the article or click here. 